\title{
Differential Expression of Vasopressin Alleles in the Brattleboro Heterozygote
}

\author{
Thomas G. Sherman and Stanley J. Watson \\ Mental Health Research Institute, University of Michigan, Ann Arbor, Michigan 48109
}

\begin{abstract}
A solution hybridization/RNase protection assay for the molar quantitation of vasopressin and oxytocin mRNAs, using synthetic complementary RNA probes, is described. This assay was optimized to permit the identification of vasopressin (AVP) mRNAs containing the frame-shift point deletion causing inheritable diabetes insipidus in the Brattleboro strain of rat. Examination of RNA from hypothalamic magnocellular tissue punches found that of the $86.1 \times 10^{-18} \mathrm{~mol}$ [86.1 attomoles (amol)] of AVP mRNA detected in the Brattleboro heterozygote paraventricular (PVN) nucleus, $5.2 \%$ could be shown to be mutant AVP mRNA (AVPd RNA). The percentage of AVPd RNA increased dramatically to $18.1 \%$ after $6 \mathrm{~d}$ of chronic intermittent salt-loading. Similar percentages and percentage increases of AVPd RNA were detected in the heterozygote supraoptic nucleus (SON). These values were contrasted with those found in parallel studies in both Long Evans and Brattleboro homozygotes, and compared with values for oxytocin (OT) mRNA in all 3 AVP rat genotypes. The results of continued osmotic regulation of the mutant AVP gene, the low native levels of AVPd RNA found in both the Brattleboro heterozygote and homozygote, and the magnitudes of AVPd expression change with chronic osmotic challenge were interpreted as indicating that (1) in the diploid rat genome, both AVP alleles are transcribed, (2) the osmotic regulation of the mutant AVP gene is normal, and (3) the low levels of AVPd mRNA are consistent with a shorter-than-control effective mRNA half-life.
\end{abstract}

Diabetes insipidus rats of the Brattleboro strain were originally shown in 1961 to contain a defect in their ability to synthesize arginine ${ }^{8}$-vasopressin (AVP) (Valtin et al., 1962). Six years later, the diabetes insipidus defect was shown to follow classic Mendelian genctics, bcing inherited as an autosomal recessive trait occurring at a single gene locus (Saul et al., 1968). Early on, however, 3 recognizable phenotypes could be distinguished, each corresponding to the known genotypes of control Long Evans rats $(\mathrm{LE},+/+)$, Brattleboro heterozygotes $(\mathrm{HZ},+/-)$, and Brattleboro homozygotes (DI, $-/-$ ). The Brattleboro $\mathrm{HZ}$ could be clearly shown to be intermediate between LE and DI animals

\footnotetext{
Received Oct. 6, 1987; revised Jan. 15, 1988; accepted Jan. 20, 1988.

This work was supported in part through NIMH Grant F32 MH09239-01 to T.G.S., NIMH Program Project Grant PO1 32422251 to S.J.W. and Huda Akil, and NIADDK Core Grant P30 AM34933-01 and a grant from the Theophile Raphael Research Fund to Huda Akil and S.J.W. Special thanks to John Sherman for designing the nonproportional spaced Helvetica font used in Figure 1.

Correspondence should be addressed to Thomas G. Sherman, Mental Health Research Institute, University of Michigan, 205 Washtenaw Place, Ann Arbor, MI 48109-0720.

Copyright (C) 1988 Society for Neuroscience $0270-6474 / 88 / 103797-15 \$ 02.00 / 0$
}

in their plasma osmolarity, rate of urinary excretion, and in ability to concentrate urine (Valtin, 1982). Other studies showed that the Brattleboro $\mathrm{HZ}$ contained plasma levels of AVP lower than LE controls (Möhring and Möhring, 1975). Thus, the mechanism of inheritance was better described as semirecessive, implicit in that nomenclature being the conclusion that the proper expression of AVP may be dependent on having 2 functional AVP alleles.

Biochemical investigations into the nature of the defect in the Brattlcboro rat progressed from the original studies, showing that AVP was absent, to in vivo labeling studies, which showed that the precursor to AVP/neurophysin I was missing (Russell et al., 1980), to in vitro cell-free translation studies, showing that mRNA from the Brattleboro hypothalamus did not code for any immunoprecipitable neurophysin precursors other than oxytocin (OT; Sherman and McKelvy, 1982). Cloning and sequencing of the Brattleboro AVP gene conclusively demonstrated that hereditary hypothalamic diabetes insipidus was due to a single base deletion in the second exon (Schmale and Richter, 1984), creating a translational frame-shift midway through the translated region. No new translational stop codon is created with this frame-shift, thus creating a relatively unique situation in which protein translation could theoretically progress into the poly(A) tail of the mutant mRNA (AVPd mRNA).

Several studies have shown that levels of AVPd mRNA in the Brattleboro DI are $45-50 \%$ of those found in either normal LE or HZ rats (Majzoub et al., 1984; Sherman et al., 1988, the preceding paper). Cell-free rabbit reticulocyte lysate experiments demonstrated that the AVPd mRNA was inefficiently translated (Schmale et al., 1984). Immunocytochemical methods confirmed this observation, in that very low, but detectable, levels of the new frame-shift created protein sequence are present in magnocellular neurons of the Brattleboro hypothalamus (Guldenaar et al., 1986; Ivell et al., 1986; Krisch et al., 1986). Various mechanisms have been put forward to explain the low in vivo expression of AVPd mRNA and its poor translatability. Although a transcriptional deficit has not been demonstrated, the gene was efficiently transcribed and correctly spliced in vitro following transfection into 3T3 cells (Schmale et al., 1984), and the regulation of the gene appears intact in vivo (Sherman et al., 1988). The burden of probable cause has centered on mechanisms of mRNA instability related to the translational defect (Sherman et al., 1988, the preceding paper).

The Brattleboro HZ, however, was shown to contain levels of AVP mRNA comparable to those found in normal LE animals (Sherman et al., 1988). This result would appear to conflict with the $\mathrm{HZ}$ semirecessive phenotype. Quantitation of HZ AVP mRNA by Northern analysis, however, did not distinguish be- 
tween AVP and AVPd RNAs, and it was unknown whether the one functional allele for AVP accounted for the total cytoplasmic expression of hybridizable AVP mRNA observed. More knowledge about the expression of AVPd mRNA relative to AVP mRNA in the Brattleboro $\mathrm{HZ}$ could explain the semirecessive phenotype of $\mathrm{HZ}$, as well as give some important information about the regulation of aberrant AVPd mRNA expression in the Brattleboro DI. Obtaining such information was dependent on a quantitative method for the detection of single base substitutions or deletions in otherwise homologous mRNAs. Methods for detecting point mutations have contributed greatly to the analysis of human disease (Chang and Kan, 1982; Orkin et al., 1982; Kidd et al., 1983; Lehrman et al., 1985; Winter et al., 1985; Gibbs and Caskey, 1987) and in the examination of DNA, RNA, and protein regulatory sequences (Myers et al., 1985c). These procedures have relied on the mutation to result in the loss or gain of a restriction endonuclease cleavage site (Chang and Kan, 1982; Orkin et al., 1982) or to exhibit differences in the melting temperatures of homologous and mutant DNA hybrids (Fischer and Lerman, 1983; Myers et al., 1985b, c). Recently, more generalized methods have been developed, which have allowed the sensitive detection of point mutations by ribonuclease cleavage at mismatches in RNA:DNA (Myers et al., 1985a) and RNA:RNA (Winter et al., 1985; Gibbs and Caskey, 1987) duplexes. These assays have taken advantage of recent strategies for the synthesis of full-length complementary RNA probes (cRNA; Green et al., 1983; Zinn et al., 1983; Melton et al., 1984). We have extended this procedure to assay cytoplasmic mRNAs for mismatches in mRNA:cRNA duplexes of AVP alleles, as well as for the simultaneous quantitation of RNAs from 2 closely related gene families: AVP and OT. We describe this assay and present its use in studies on the regulation of expression of individual AVP alleles in the Brattleboro HZ.

\section{Materials and Methods}

Chronic intermittent salt-loading. Nine-week-old male LE rats and male Brattleboro HZs and DIs were purchased from Blue Spruce Farms (Altamont, NY). Brattleboro DIs were bred in DI mothers mated with DI males, while HZs were bred from LE mothers mated with DI males. The rats were individually caged on a $12 \mathrm{hr}$ light/dark cycle $(0600 \mathrm{on}$, $1800 \mathrm{off}$ ) and maintained with free access to water and Purina Lab Rodent Chow for $7 \mathrm{~d}$ prior to salt-loading. The chronic intermittent salt-loading (CISL) regimen, as previously described (Sherman et al., 1988 , the previous paper), involved the substitution of $2 \%(\mathrm{wt} / \mathrm{vol})$ sodium chloride $(0.34 \mathrm{M} \mathrm{NaCl})$ for drinking water from $1600 \mathrm{hr}$ until $1000 \mathrm{hr}$, with fresh normal water present for the remaining $6 \mathrm{hr}$. The amount of water or saline consumed and rat body weights were recorded at the end of each time period (1000 and $1600 \mathrm{hr})$ and have been reported in detail elsewhere (see Sherman et al., 1988). On day 6 , the animals were killed by decapitation at $1000 \mathrm{hr}$, and the hypothalamic magnocellular nuclei (PVN and SON) were fresh-dissected from $\sim 1.0$ mm sagittal sections through the hypothalamus, using a modification of the Palkovits punch procedure, as previously described (Sherman et al., 1986b).

Isolation of total nucleic acids. For characterization of the solution hybridization/RNase protection assay, including $R_{0} t$ hybridizations and linearity experiments, total cytoplasmic RNA was isolated from pooled SON tissue punches using a modification of the $\mathrm{CsCl}$ /guanidinium isothiocyanate method, as previously described (Sherman et al., 1986a). For CISL experiments, total nucleic acids were extracted from single tissue punches by homogenization in $0.3 \mathrm{ml}$ LET buffer: $10 \mathrm{~mm}$ Tris$\mathrm{HCl}, \mathrm{pH} 7.5,10 \mathrm{~mm}$ EDTA, and $1 \%$ (wt/vol) of $36.7 \mathrm{~mm}$ lithium dodecyl sulfate containing $0.1 \mathrm{mg} / \mathrm{ml}$ proteinase $\mathrm{K}$. The homogenate was incubated at $42^{\circ} \mathrm{C}$ for $1 \mathrm{hr}$, extracted once with buffered phenol, once with phenol: chloroform, and once with chloroform. All RNAs and nucleic acids were stored under $70 \%$ ethanol at $-20^{\circ} \mathrm{C}$ until use. In all of the methods, the use of phenol implies redistilled phenol buffered with Tris-
IICl, pII 8.0; the use of chloroform implies $24: 1$ chloroform : isoamyl alcohol, and the use of phenol/chloroform implies a $1: 1(\mathrm{vol} / \mathrm{vol}) \mathrm{mix}-$ ture of phenol and chloroform.

Cloning, synthesis and isolation of $c R N A$ hybridization probes. CDNAs for the AVP/neurophysin I and OT/neurophysin II precursors were identified and isolated from a Sprague-Dawley rat lambda gt 10 hypothalamic cDNA library. Selected cDNAs for each prohormone were subcloned into pSP6 or pGEM plasmids (Promega Biotec, Madison, WI); cloned poly(A) tails were removed by appropriate restriction enzyme cleavages to permit more efficient transcription. The $2 \mathrm{cDNA} /$ plasmid constructs used predominantly in this study, pGEM3-AVP4c and pSP65-OXY14c, were both oriented in their plasmids such that transcription by SP6 RNA polymerase yielded RNA complementary to endogenous mRNA (see Fig. 2 of Sherman et al., 1988).

Transcription of linearized pGEM plasmids containing AVP or OT cDNA inserts were performed in a $20 \mu$ l volume, essentially as described by Promega Biotec. Typically, the reaction contained $1.0 \mu \mathrm{g}$ linearized plasmid and $150-200 \mathrm{Ci} / \mathrm{mmol} \alpha-{ }^{32} \mathrm{P}-\mathrm{CTP}$. The reaction was incubated at $40^{\circ} \mathrm{C}$ for $60 \mathrm{~min}$. One-tenth volume of sterile $10 \times$ loading buffer ( $25 \%$ Ficoll, type $400 ; 0.25 \%$ xylene cyanol) was added to the reaction, and the entire mixture loaded onto a $1 \%$ (wt/vol) low-melting-point agarose gel (Bethesda Research Labs, Gaithersburg, MD) made in $1 \times$ TAE buffer: $40 \mathrm{~mm}$ Tris-acetate, $2 \mathrm{~mm}$ EDTA, $0.5 \mathrm{\mu g} / \mathrm{ml}$ ethidium bromide. The reaction was electrophoresed at $50 \mathrm{~V}$ until the slightly fuzzy RNA band, visualized by UV light, was clearly separated from the plasmid template. The cRNA band was excised, melted in $0.25 \mathrm{ml}$ sterile water at $65^{\circ} \mathrm{C}$, and extracted once at $4^{\circ} \mathrm{C}$ with 1 vol of buffered phenol. The aqueous phase was extracted with 1 vol of chloroform, and the cRNA coprecipitated with $20 \mu \mathrm{g}$ glycogen (901 393; Boehringer Mannheim Biochemicals, Indianapolis, IN) from $25 \mathrm{~mm}$ sodium acetate, $\mathrm{pH} 5.2$, with 2.5 vol of ethanol.

Solution phase hybridization. Solution phase hybridization was performed in a modification of the procedure of Myers et al. (1985a). The procedure was modified to permit the addition of aqueous solutions of total RNA or nucleic acids. Hybridizations were conducted in a $30 \mu 1$ volume in $0.5 \mathrm{ml}$ Eppendorf tubes. Formamide was freshly deionized prior to each experiment with Chelex 100 (Bio-Rad, Richmond, CA) and the mixed-bed resin $A G 501-X 8(D)$ for $60 \mathrm{~min}$ at $22^{\circ} \mathrm{C}$; deionized formamide was recovered by filtration through a $0.22 \mu \mathrm{m}$ Millex-GS filter unit (Millipore, Bedford, MA). Pelleted ${ }^{32}$ P-labeled cRNA was resuspended 5 times in solution hybridization buffer (SHB) at a concentration of $4.17 \mu \mathrm{M}(25 \mathrm{fmol} / 6.0 \mu \mathrm{l})(5 \times$ SHB: 0.2 PIPES, pH. 6.4 $2.0 \mathrm{M} \mathrm{NaCl}, 5.0 \mathrm{~mm}$ EDTA). Each hybridization raction containcd 6.0 $\mu 15 \times$ SHB containing 25 fmol cRNA, $15.0 \mu$ ldeionized formamide, $4.0 \mu \mathrm{l}(5.0 \mathrm{mg} / \mathrm{ml})$ yeast RNA, and $5.0 \mu 1$ total RNA or nucleic acids in water. The reaction was incubated at $85^{\circ} \mathrm{C}$ for $5 \mathrm{~min}$ and submerged in a $50^{\circ} \mathrm{C}$ water bath for $5 \mathrm{hr}$.

RNase digestion. Ribonuclease A (R-5125; Sigma) was made deoxyribonuclease-free as previously described (Maniatis et al., 1982). Hybridization reactions were cooled to room temperature. To each was added $0.2 \mathrm{ml}$ of RNase digest buffer: $10 \mathrm{~mm}$ Tris- $\mathrm{HCl}, \mathrm{pH} 7.5,5.0 \mathrm{~mm}$ EDTA, $0.2 \mathrm{M} \mathrm{NaCl}, 0.1 \mathrm{M} \mathrm{LiCl}$ containing $40 \mu \mathrm{g} / \mathrm{ml}$ RNase A and 1000 $\mathrm{U} / \mathrm{ml}$ RNase $\mathrm{T}_{1}$ (Bethesda Research Labs). Digestion continued at $22^{\circ} \mathrm{C}$ for $30-120 \mathrm{~min}$. The reaction was stopped by the addition of $10 \mu \mathrm{l} 20 \%$ (wt/vol) SDS and $10 \mu \mathrm{l}$ proteinase $\mathrm{K}(10 \mathrm{mg} / \mathrm{ml}$; Bethesda Research Labs). The reaction was incubated at $30^{\circ} \mathrm{C}$ for $15 \mathrm{~min}$ and at $37^{\circ} \mathrm{C}$ for $30 \mathrm{~min}$. Protected fragments were recovered after phenol/chloroform extraction by ethanol coprecipitation with $20 \mu \mathrm{g}$ glycogen. RNase A is a single-stranded endoribonuclease that cleaves between the $3^{\prime}$ phosphate of pyrimidines $(\mathrm{C}, \mathrm{U})$ and the $5^{\prime}$ hydroxyl of adjacent nucleotides. RNase $T_{1}$ is a single-stranded endoribonuclease that cleaves between the $3^{\prime}$ phosphate of guanines (G) and the $5^{\prime}$ hydroxyl of adjacent nucleotides.

Electrophoresis. Protected cRNA:mRNA fragments were fractionated on $4 \%$ polyacrylamide gels in TBE buffer: $89 \mathrm{~mm}$ Tris, $89 \mathrm{~mm}$ boric acid, 2 mM EDTA (nondenaturing gels). Denaturing gels contained the addition of $7 \mathrm{M}$ urea. Maximum resolution occurred on 0.4-mm-thick gels with a $0.25 \%$ xylene cyanol and $0.25 \%$ bromophenol blue loading buffer containing either $20 \%$ formamide (nondenaturing gels) or $50 \%$ formamide (denaturing gels); one glass plate was derivatized with $\gamma$-methacryloxypropyl-trimethoxy silane (MPTS) (Sigma M-6514): $25 \mu \mathrm{l}$ MPTS was diluted in $5.0 \mathrm{ml}$ of $50 \mathrm{~mm}$ acetic acid (left on glass $3 \mathrm{~min}$, washed with $95 \%$ ethanol). The other plate was silanized normally with $10 \%$ dimethyldichlorosilane (Sigma D-3879) in chloroform. Following electrophoresis, the plates were separated, and the derivatized plate with 
AGCAGAGCAG AGCUGCACGC AGUGCCCACC UAUGCUCGCC AUGAUGCUCA AAACCAUCA CCGACGGUGG AUCUCGGACU GAACACCAAC GCC - - - GC - U - OT14c

ACACUACGCU CUCUGCUUGC UUCCUGAGCC UGCUGGCCCU CACCUCUGCC

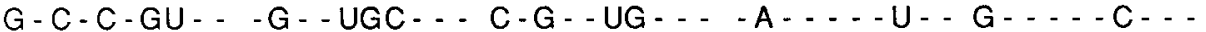

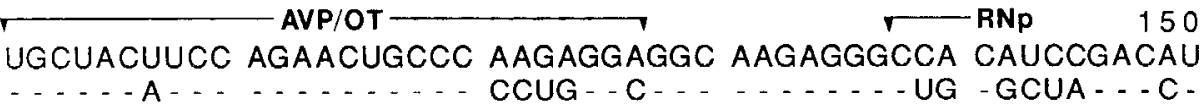
TAVP4C 200

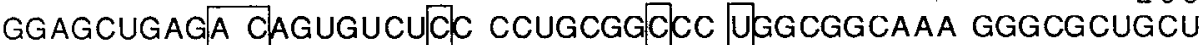

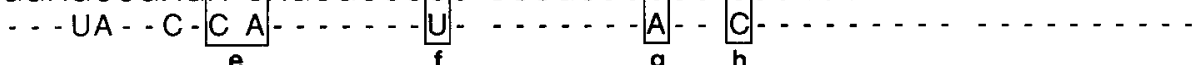
a UCGGGCCGAG CAUCUGCUGC GCGGACGAGC UGGGCUGCUU CQUGGGCACC $\ldots \ldots \ldots \ldots \ldots \ldots \ldots \ldots \ldots \ldots \ldots \ldots . \ldots \ldots \ldots$ GCCGAGGCGC UGCGCUGCCA GGAGGAGAAC UACCUGCCCU CGCCCUGCCA

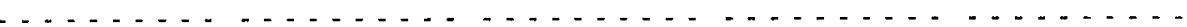

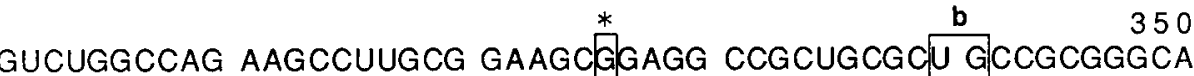

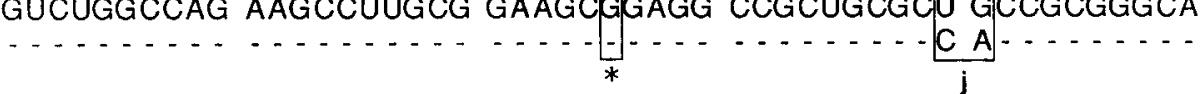
$\begin{array}{llll}\text { c } & \text { d } & 400\end{array}$ UCUGCUG ..... - - - . CCG - - UG - . - CGCA - - - . - CC - CGACCCU - AG k RNp 1 OT14C 450 UUUUUCCGCC UCACCCGCGC UCGGGAGCAG AGCAACGCCA CGCAGCUGGA - C - GC - UU - U C - GAG - - - $\underline{U G} \underline{A}$

500 CGGGCCAGCC CGGGAGCUGC UGCUUAGGCU GGUACAGCUG GCUGGGACAC

Gp $\longrightarrow$

550

AAGAGUCCGU GGAUUCUGCC AAGCCCCGGG UCUACUGAGC CAUCGCCCCC GC CCUGCUUUGU

\author{
AVP4C $\longrightarrow$
}

600

CACGCCUCCC CCCUACAGCA UGGAAAAUAA ACUUUUAAAA AAAAAAAAAA GAUGAUACCU UUAGGGCGCU UCCUUCAUUC CCCAUGGCCA CUACCAAAAA
Figure 1. Nucleotide sequences of AVP/RNp I (top) and OT/RNp II (bottom) mRNAs. Dashes indicate nucleotide agreement. The extent of the SP6 RNA polymerase $c$ RNA transcript from pGEM3-AVP4c $(A V P 4 C)$ is indicated (190-586), as is the transcript from pSP65-OXY14c (OT 14C; 15-387). Nuclcotide scquences 5 ' to positions AVP 28 and OT 15 are taken from Ivell and Richter (1984). The point of the Brattleboro point deletion is boxed at position $326\left(^{*}\right)$. The boxes enclose mismatches in the midregion between AVP and OT mRNAs; the small letters above and/or below each box ascribe the heterologous mRNA:cRNA mismatch of that strand to Table II. The underlined UGA triplets indicate translational stop codons. The double-underlined $\mathrm{A}$ at position 577 marks a nucleotide difference between this OT cDNA and that reported carlier (Ivell and Richter, 1984). The gap in the OT mRNA sequence starting at 422 encompasses the glycoprotein $(G p)$ carboxyl terminus of provasopressin/RNp I absent in pro-oxytocin/RNp II. $s p$, Translational start site marking the beginning of the signal peptide region. $A V P / O T$, Nucleotide region encoding the nonapeptide hormones vasopressin and OT. $R N p$, Nucleotide sequences encoding the rat neurophysin proteins. attached gel dried in an oven at $80^{\circ} \mathrm{C}$ for $45 \mathrm{~min}$ (if a denaturing gel, the first wash was in $10 \%$ acetic acid for $20 \mathrm{~min}$ to remove urea).

Quantitation. Kodak X-Omat XAR5 film was used for direct-contact autoradiography. After a good exposure was obtained, the well-separated, individual bands were scraped from the glass plate and placed in a $20 \mathrm{ml}$ scintillation vial. The RNA in the gel piece was hydrolyzed to nucleotide monophosphates by swelling the gel pieces in $1.0 \mathrm{ml}$ of 50 $\mathrm{mN} \mathrm{NaOH}$ at $37^{\circ} \mathrm{C}$ for $14 \mathrm{hr}$. The mixture was neutralized with $1.0 \mathrm{~N}$ $\mathrm{HCl}$. Ten milliliters of scintillation fluid (Safety Solve; RPI, Mount Prospect, IL) was added, and the mixture shaken for $30 \mathrm{~min}$ and counted.

Total integrated optical density (IOD) for all individual bands was determined by densitometry, using a Loats image analysis system (Westminster, MD). For each individual $\mathrm{x}$-ray film autoradiogram, a dpm/ IOD correlation factor was determined using disintcgrations per minute $(\mathrm{dpm})$ values for bands from the gel that could be cleanly scraped and counted. With this method, dpm values for all bands could be determined, including those for closely apposed bands that could not be clearly scraped and individually counted. Typically, the determined $\mathrm{dpm}$ values related to IOD values with an intragel correlation coefficient of $r>0.995$. dpms were converted to mole equivalents with information based on the specific activity of the cRNA probe, the fre- quency of the labeled nucleotide, and the deduced sequence of the protected cRNA band. All dpm and specific activity values derived from an experiment were corrected to the first day of that particular experiment to control for ${ }^{32} \mathrm{P}$ half-life. All values are expressed as mean \pm SEM. An attomole (amol) equals $10^{-18} \mathrm{~mol}$, or approximately 602,257 molecules.

\section{Results}

mRNA:cRNA solution hybridization/RNase protection assay Identification of protected bands. Prior to the initiation of solution hybridization/RNase protection studies for AVP and OT mRNA quantitation, it was predicted, on the basis of primary sequence information, that the regions containing near perfect homology between AVP and OT mRNAs would serve as both a complicating factor, in that a multitude of protected mRNA: cRNA fragments might be generated, and as a bonus, in that 2 different mRNAs might be effectively quantitated with one probe. Figure 1 presents and contrasts the sequences of AVP and OT mRNAs. Between the nucleotide positions of 162 and 339 , with- 


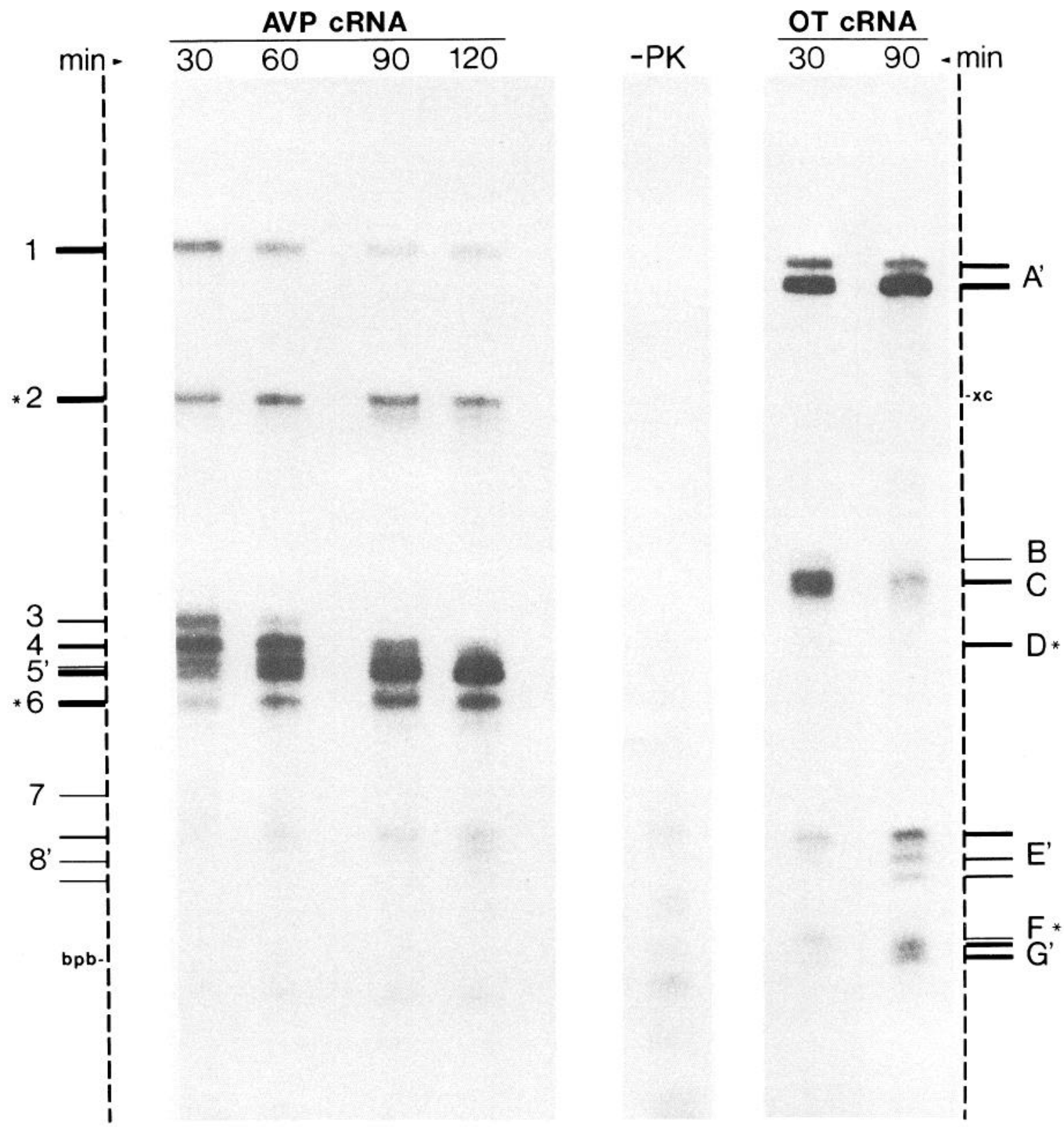

Figure 2. Time course of RNase A/T, digestion for mRNA:cRNA hybrids. Bands generated by the Brattleboro deletion are indicated by *; artifactual doublet and triplet bands are primed ('). AVP $c R N A$, Protection of AVP cRNA by RNA isolated from homozygous Brattleboro SON. Total nucleic acids were LET-extracted from 4 combined SON nuclei from control DI rats as described in Materials and Methods, and ethanolprecipitated in 4 separate aliquots. Each pellet was hybridized against $49.6 \mathrm{fmol}\left(1.54 \times 10^{6} \mathrm{dpm}\right)$ of ${ }^{32} \mathrm{P}-$ labeled AVP cRNA for $5 \mathrm{hr}$ at $50^{\circ} \mathrm{C}$ in $50 \%$ formamide hybridization buffer. The $22^{\circ} \mathrm{C}$ RNase digestion for each time point was terminated by the addition of SDS and proteinase $\mathrm{K}$, with subsequent incubations and phenol extractions, as described, and fractionated on a $4 \%$ acrylamide, $7 \mathrm{M}$ urea gel. $-P K$, Protection of AVP cRNA by homozygous Brattleboro SON RNA as just described, except that the RNase digestion was terminated by SDS and phenol extraction, omitting the proteinase $\mathrm{K}$ digestion step. OT $c R N A$, Protection of OT cRNA by RNA isolated from $6 \mathrm{~d}$ CISL heterozygous Brattleboro SON. The 2 lanes, taken from 2 different gels run in parallel, each contain the total nucleic acids isolated from one SON. Each pellet was hybridized against $35.6 \mathrm{fmol}\left(1.41 \times 10^{6} \mathrm{dpm}\right)$ of ${ }^{32} \mathrm{P}$-labeled OT cRNA for $5 \mathrm{hr}$ at $50^{\circ} \mathrm{C}$ in $50 \%$ formamide hybridization buffer, RNase-digested, and electrophoresed as above. $x c$, Xylene cyanol. $b p b$, Bromophenol blue. Electrophoretic origin not shown.

in the sequence encoding the highly homologous rat neurophysin proteins (RNp I and II), the 2 gene products possess nearly $98 \%$ homology, and contain 2 stretches of $100 \%$ homology that are 60 and 97 bases in length. It is within this conserved region (position 326) that the point deletion causing diabetes insipidus occurs. All, or a major portion, of the 2 high-homology regions, as well as the Brattleboro deletion site, are spanned by the 2 cRNA probes synthesized for the studies presented here. SP6
RNA polymerase transcription of EcoRI-linearized pGEM3AVP4c makes a 461-nucleotide RNA, containing 397 nucleotides of AVP cRNA (positions 190-586; Fig. 1; asterisks). Transcription of HindIII-linearized pSP65-OXY14c generates a 463-nucleotide RNA containing 373 nucleotides of OT cRNA (positions 15-387, Fig. 1); see Figure 3 of Sherman et al. (1988; the previous paper) for a schematic of these plasmid constructs.

The characterization of the RNase protection assay progressed 


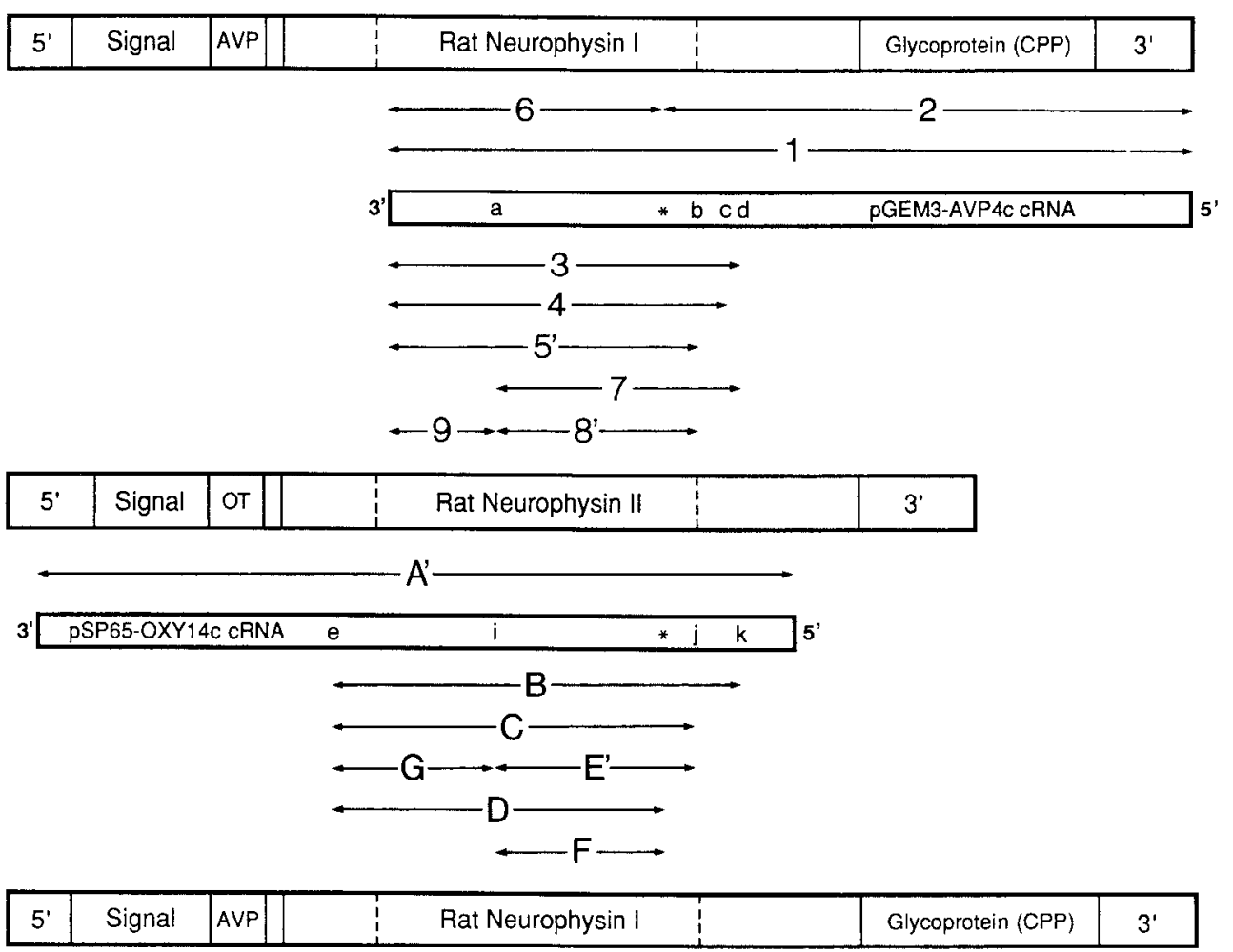

Figure 3. Orientation and derivation of protected cRNA bands. Schematized AVP and OT mRNAs are contrasted with the 2 cRNAs used in this study. Each identified cRNA band is situated between its position in the cRNA and that rcgion of heterologous mRNA protecting it. The small letters $a-k$ correspond to the positions of designated mismatches described in Figure 1 and Table II, with the Brattleboro deletion site marked with an *. Large $5^{\prime}$ and $3^{\prime}$, $5^{\prime}-$ and $3^{\prime}$-untranslated regions of mRNA. Small $5^{\prime}$ and $3^{\prime}, 5^{\prime}$ and $3^{\prime}$ ends of cRNA probes. Sequences between dashed lines of RNp I and II, regions of $98 \%$ homology. Signal, signal peptide. through 2 stages: first, a time course of RNase digestion to identify an incubation length and temperature that maximized endoribonuclease cleavage at sites of mismatch and deletion, as well as minimized the loss of protected cRNA; and, second, to optimize solution hybridization for mRNA quantitation by ensuring both assay linearity and probe saturation.

Figure 2 shows the denaturing electrophoretic separation of ${ }^{32} \mathrm{P}$-labeled AVP cRNA fragments protected by DI Brattleboro SON mRNA (left) and of OT cRNA fragments protected by CISL-treated HZ Brattleboro SON mRNA (right). DI SON and CISL HZ SON mRNAs were chosen for Figure 2 because all bands protected by LE, HZ, and DI hypothalamic mRNAs can be easily observed for illustration purposes. On the basis of both internal and synthetic RNA molecular-weight standards, each of the observed protected bands has been tentatively identified. The derivation and interrelationships of all observed bands are schematized in Figure 3 and discussed below.

Band 1 is the 397-nucleotide full-length protected AVP cRNA. Protection by DI hypothalamic mRNA yielded 2 additional bands, 2 and 6, which migrated at the sizes predicted (260 and 136 bases, respectively) if cleavage at the deletion site occurred. Table IA shows that during the time course of RNase $A / T_{1}$ digestion, the averaged molar increases in bands 2 and 6 approximately equaled the molar loss in band 1 . The efficiency of cleavage at the point deletion mismatch at 90 min was $83 \%$ (see Table IIA). The remaining bands observed in Figure 2 are those protected by the high-homology regions of OT mRNA. Bands 3-5', easily discernible at $30 \mathrm{~min}$ of RNase digestion, were processed to a single major band, 5', by the $2 \mathrm{hr}$ time point. Band $5^{\prime}$, depicted in Figure 3, is a 151-nucleotide cRNA protected by the region of near perfect homology within the OT mRNA (position 190-339). The single mismatch within this region, a $\mathrm{G}: \mathrm{G}$ pairing at position 242 , was partially cut to generate the
82 -nucleotide band $8^{\prime}$ and the 52-nucleotide band 9 , too small to be detected in the gel system used here.

The protection of OT cRNA by $\mathrm{HZ}$ mRNA yielded a doublet of full-length protected bands $A^{\prime}$. The prime ('), also used above for bands $5^{\prime}$ and $8^{\prime}$, describes 2 or more bands thought to derive from one band throught no obvious cleavage site, caused by mismatch (Myers et al., 1985a). The band $A^{\prime}$ doublet was retained throughout the $90 \mathrm{~min}$ RNase digest (Fig. 2), as well as in digest temperatures of 15 and $30^{\circ} \mathrm{C}$ (data not shown). A good explanation for the occurrence of this highly reproducible artifact has not been found. Band $C$ represents the complete 179nucleotide high-homology region between AVP and OT mRNAs. When protected by the deletion containing AVP mRNA of DI hypothalamus (AVPd mRNA), band $C$ was cleaved into the 164-nucleotide band $\mathrm{D}$ and a 14-nucleotide piece too small to be detected. The single mismatch within the high-homology region, this time being a $\mathrm{C}: \mathrm{C}$ mismatch, was more effectively cleaved by RNase $A$ to yield bands $E^{\prime}$ and $G^{\prime}$. In Figure 2, bands $E^{\prime}$ are directly analogous to bands $8^{\prime}$, protected in AVP cRNA, both displaying triplet bands migrating at identical $R_{\mathrm{f}}$ valucs. When the log of the tentatively assigned band lengths for protected fragments of Figure 2 were plotted against electrophoretic mobility, the points described a straight line with a correlation coefficient of $r=0.997$.

In an attempt to simplify and shorten the RNase protection assay, the necessity of postdigesting the RNase reaction with proteinase $\mathrm{K}$ was investigated. Lane $-\mathrm{PK}$ (Fig. 2) shows that phenol $/ \mathrm{CHC}_{3}$ extraction alone was not sufficient to remove all RNase. When the mRNA:cRNA duplex was denatured prior to denaturing electrophoresis, the ssRNA became the substrate for remaining $\mathrm{RNase}$. With nondenaturing electrophoresis, this was not as great a problem.

Table I summarizes the results of the RNase digestion time 
Table I. RNase $A / T_{1}$ Time Course with mRNA:cRNA hybrids.

A . EcoRI-cut pGEM3-AVP4c cRNA fragments protected by control DI SON RNA:

\begin{tabular}{|c|c|c|c|c|c|c|c|}
\hline \multicolumn{3}{|c|}{ Protecting } & & \multicolumn{4}{|c|}{ Attomoles of AVP cRNA Fragments } \\
\hline Band\# & mRNA & Length & Position ${ }^{\diamond}$ & $30 \mathrm{~min}$ & $60 \mathrm{~min}$ & $90 \mathrm{~min}$ & $120 \mathrm{~min}$ \\
\hline$\underline{1}^{\star}$ & VPd & 396 & $\# 190-586$ & 35.3 & 26.8 & 16.3 & 15.2 \\
\hline$\underline{2}^{*}$ & VPd & 260 & $\# 327-586$ & 49.0 & 57.7 & 62.8 & 57.7 \\
\hline$\underline{3}$ & OT & $>182$ & $\# 190>371 \S$ & 38.1 & 13.5 & 2.2 & 0.0 \\
\hline$\underline{4}$ & OT & 172 & $\# 190-361$ & 46.6 & 44.3 & 33.2 & 18.8 \\
\hline$\underline{5}^{\prime}$ & OT & 151 & $\# 190-340$ & 44.4 & 62.0 & 71.6 & 81.3 \\
\hline$\underline{6}^{*}$ & VPd & 136 & $\# 190-325$ & 49.2 & 59.5 & 66.1 & 62.9 \\
\hline 7 & OT & 120 & $\# 242-361$ & 3.0 & 2.3 & 0.0 & 0.0 \\
\hline$\underline{8}^{\prime}$ & OT & 98 & $\# 243-340$ & 5.1 & 15.4 & 21.6 & 19.8 \\
\hline 2 & OT & 52 & $\# 190-241$ & - & - & - & - \\
\hline Tota & covery & VP $\mathrm{mRN}$ & & $100.0 \%$ & $100.1 \%$ & $95.7 \%$ & $89.5 \%$ \\
\hline Tota & covery 0 & OT mRN & & $100.0 \%$ & $100.1 \%$ & $94.6 \%$ & $87.5 \%$ \\
\hline
\end{tabular}

B . HindIII-cut pSP65-OXY14c cRNA fragments protected by CISL HZ SON RNA:

\begin{tabular}{|c|c|c|c|c|c|c|c|}
\hline \multicolumn{3}{|c|}{ Protecting } & \multirow[b]{2}{*}{ Position ${ }^{\circ}$} & \multicolumn{4}{|c|}{ Attomoles of OT cRNA Fragments } \\
\hline Band\# & mRNA & Length & & $30 \mathrm{~min}$ & $60 \mathrm{~min}$ & $90 \mathrm{~min}$ & $120 \mathrm{~min}$ \\
\hline$\underline{A}^{\prime}$ & OT & 373 & \# $15-387$ & 128.7 & n.d. & 122.4 & n.d. \\
\hline$\underline{\mathrm{B}}$ & VP & 201 & $\# 161-361$ & 29.2 & n.d. & 0.0 & n.d. \\
\hline$\underline{\mathrm{C}}$ & VP & 179 & $\# 161-339$ & 165.4 & n.d. & 53.0 & n.d. \\
\hline$\underline{D}^{*}$ & VPd & 165 & $\# 161-325$ & 16.6 & n.d. & 61.1 & n.d. \\
\hline$\underline{E}^{\prime}$ & $\mathrm{VP}$ & 98 & $\# 242-339$ & 57.1 & n.d. & 148.1 & n.d. \\
\hline$\underline{F}^{\star}$ & VPd & 84 & $\# 242-325$ & n.d. & n.d. & n.d. & n.d. \\
\hline$\underline{\mathrm{G}^{\prime}}$ & VP & 81 & $\# 161-241$ & 61.1 & n.d. & 132.5 & n.d. \\
\hline Tota & covery & OT $\mathrm{mRN}$ & & $100.0 \%$ & & $95.1 \%$ & \\
\hline Tota & covery & VP $\mathrm{mRN}$ & & $100.0 \%$ & & $94.2 \%$ & \\
\hline
\end{tabular}

Values represent the average of two determinations $\quad$ VPd $=$ deletion containing AVP mRNA

* = fragments protected by AVPd mRNA $\quad \diamond=$ refers to Figure $1 \quad \S=$ no one clear site

$5^{\prime}$ or $\mathrm{A}^{\prime}$ etc. = family of bands generated from one primary band by RNase nibbling from ends 


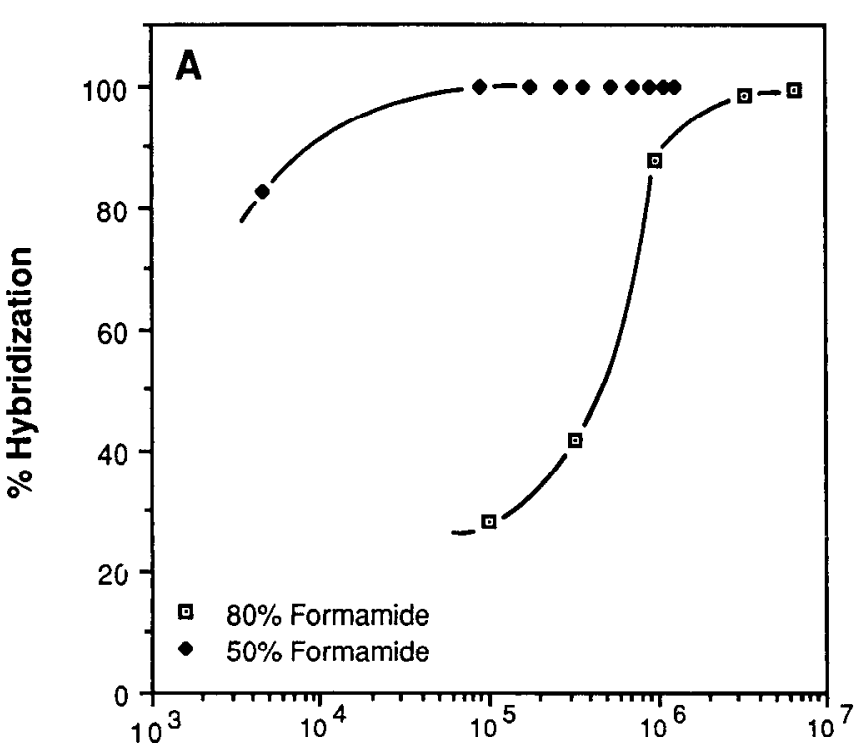

Rot (fmole-sec) AVP cRNA

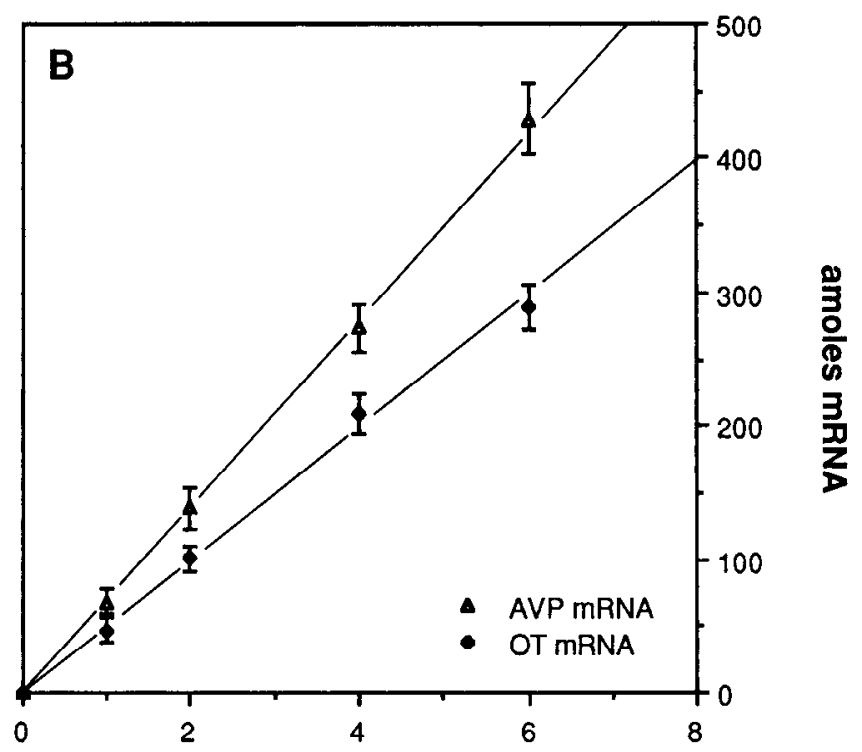

ug SON RNA

Figure 4. A, Characterization of the solution phase hybridization/RNase protection assay. $R_{0} t$ saturation analysis: The results of 2 separate experiments are plotted. The $80 \%$ formamide hybridizations consisted of $\Lambda$ VP cRN $\Lambda$ hybridized against $5.0 \mu \mathrm{g}$ Long Evans SON RNA. The LE RNA was coprecipitated with $20 \mu \mathrm{g}$ yeast RNA/tube, and the pellets resuspended in $30 \mu \mathrm{l}$ of $80 \%$ formamide hybridization buffer containing 5.46 , $18.20,54.60,182.00$, or $362 \mathrm{fmol}$ cRNA probe $(25,000 \mathrm{dpm} / \mathrm{fmol})$. Hybridization proceeded at $50^{\circ} \mathrm{C}$ for $5 \mathrm{hr}$, and was prepared for nondenaturing gel electrophoresis as described. Only the results of band 1 are presented. The point of $100 \%$ hybrid formation is the extrapolation of the data. The $50 \%$ formamide hybridizations consisted of $42.7 \mathrm{fmol}\left(3.42 \times 10^{6} \mathrm{dpm}\right)$ AVP cRNA hybridized against $5.0 \mu \mathrm{g}$ of LE SON RNA in the $50 \%$ formamide hybridization buffer for from 0.5 to $9.0 \mathrm{hr}$. At the end of each time period, the hybridization mixtures were frozen in liquid nitrogen. At the end of the hybridization period, all the frozen reactions were diluted with RNase digest buffer containing $\mathrm{RNase} A / \mathrm{T}_{1}$ at $22^{\circ} \mathrm{C}$. The samples were prepared for nondenaturing electrophoresis, as described. The point of $100 \%$ hybrid formation was the mean of the $2-9 \mathrm{hr}$ time points. Again, only the results from band 1 are shown. $B$, Linearity: The linearity of the assay was checked in triplicate with $31.4 \mathrm{fmol}\left(1.88 \times 10^{6}\right.$ dpm) of AVP cRNA probe hybridized against $0,1,2,4$, and $6 \mu \mathrm{g}$ of LE SON RNA. One magnocellular tissue punch yields approximately $2.0-2.5 \mu \mathrm{g}$ of RNA. The hybridization was for $5 \mathrm{hr}$ at $50^{\circ} \mathrm{C}$ in $50 \%$ formamide. The protected bands were fractionated on a $4 \%$ nondenaturing gel. Values are means + SEM, $n=3$.

course for both cRNA probes. It also presents calculated total recoveries for both AVP and OT mRNAs. With longer RNase digestion times, gains made in the cleavage of base-pair mismatches were offset by decreases in the total recovery of protected bands. Losses were probably due to nonspecific endonuclease "nicking" within protected regions, since the degree of recovery was indirectly proportional to band length. Band 6, for example, exhibited a greater degree of recovery relative to band 2 ; the $6 / 2$ ratio progressed from $1.00,1.03,1.05$, to 1.09 during the 30-120 min digestions, respectively. Beginning after the first half-hour of digestion, overall losses approximated 6\% for each additional $30 \mathrm{~min}$. Losses of greater than $10 \%$ after 90 min of digestion began to contribute significantly to the autoradiographic background. In a compromise, both of the efficiencies of mismatch and deletion cleavage and to attain quantitative recoveries, $90 \mathrm{~min}$ at $22^{\circ} \mathrm{C}$ was chosen as the standard assay condition. This afforded an $83 \%$ efficiency of cleavage at the Brattleboro deletion site and an overall recovery greater than $94 \%$.

Saturation and linearity. The kinetics of mRNA:cRNA hybridization were determined for 2 different assay conditions at $50^{\circ} \mathrm{C}$ : hybridization in $80 \%$ formamide, as originally described (Myers et al., 1985a), and in 50\% formamide. Adaptation to the latter condition was of particular interest, because it allowed the extra volume necessary for the addition to each assay tube of an aqueous mRNA sample. This obviated the need to pellet each assay sample, avoided the difficulties in resuspending nu- cleic acid pellets in formamide buffers, and eased the assay of multiple aliquots from the same sample. Figure $4 A$ compares saturation curves obtained for each of the 2 assay conditions. When hybridized against $5.0 \mu \mathrm{g}$ of control LE SON RNAapproximately the amount of RNA obtained from 2 SON tissue punches (Sherman et al., 1986a)-saturating hybridization occurred at $R_{0} t$ values of $10^{5}$ and $7 \times 10^{6} \mathrm{fmol}$-sec in $50 \%$ and $80 \%$ formamide, respectively. To reach saturation during a 5 hr hybridization at $50^{\circ} \mathrm{C}$, these $R_{0} t$ values predict the requirements of 5.56 and 389 fmol of cRNA probe, respectively. A typical SP6 RNA polymerase transcription of an $\sim 500$ bp insert with $1.0 \mu \mathrm{g}$ of linearized plasmid yields approximately 1000 fmol of cRNA; therefore, a $5 \mathrm{hr}$ hybridization containing greater than $25 \mathrm{fmol}$ of ${ }^{32} \mathrm{P}$-labeled cRNA at $50^{\circ} \mathrm{C}$ in $50 \%$ formamide was adopted as more than adequate for most assays consisting of 20-40 samples. Under these conditions, the assay was linear through $6.0 \mu \mathrm{g}$ of total SON RNA (Fig. $4 B$ ).

\section{Quantitation of AVP and OT mRNA expression during CISL}

Expression of both AVP alleles in the Brattleboro HZ. Total nucleic acids isolated from individual PVN and SON tissue punches dissected from control and CISL animals were assayed for AVP and OT mRNA content with both cRNA probes, using the RNase protection assay. Figure 5 shows the autoradiographic results obtained when AVP cRNA-protected fragments were electrophoresed on a denaturing gel. Magnocellular RNA from the LE rat protects 2 main species of cRNA: band 1, the full- 


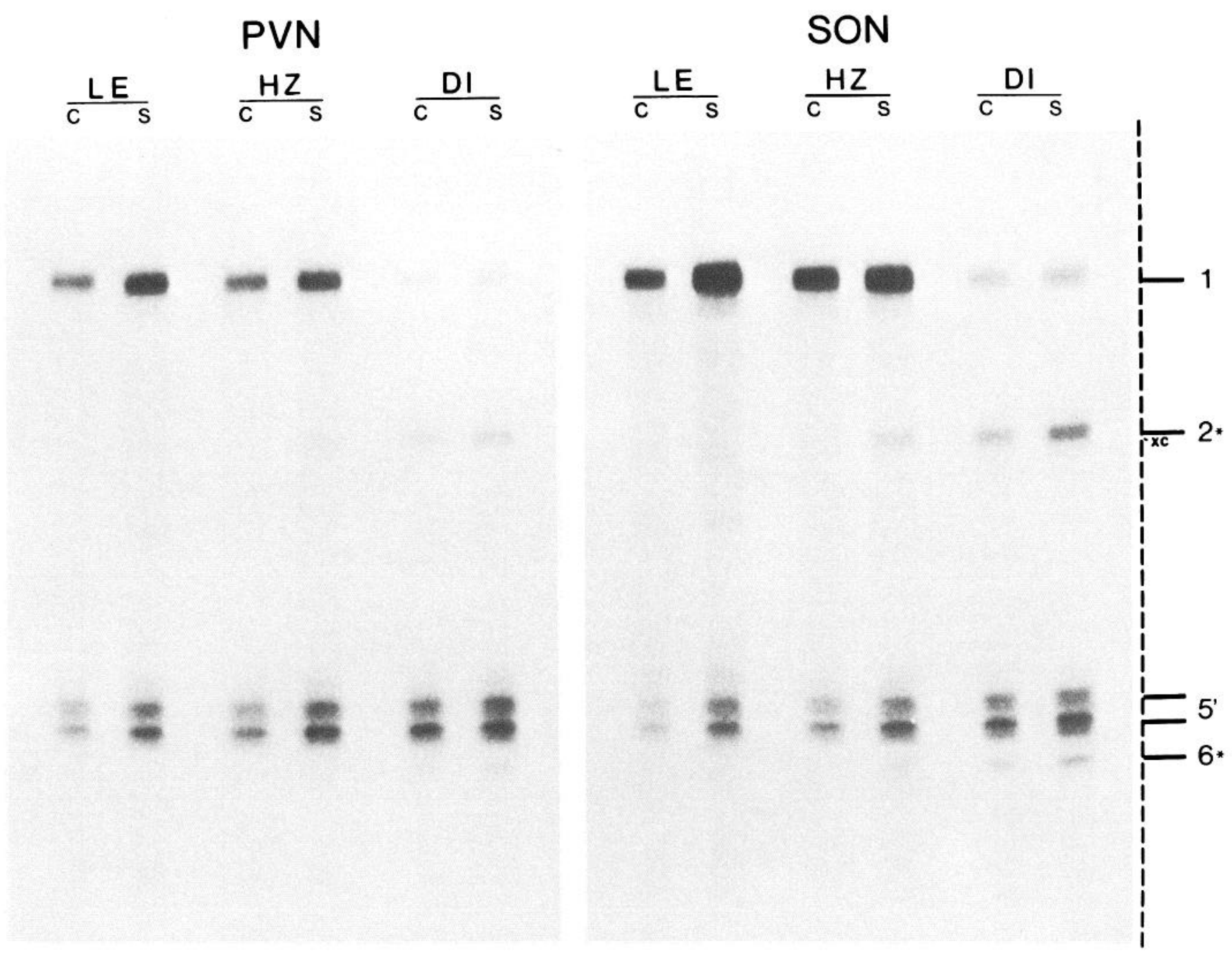

Figure 5. Denaturing gel electrophoresis of AVP cRNA fragments protected by control and CISL RNAs. Total nucleic acids from individual magnocellular PVN and SON tissue punches were isolated, hybridized against $44.22 \mathrm{fmol}\left(1.76 \times 10^{6} \mathrm{dpm}\right)$ of AVP cRNA in 50\% formamide hybridization buffer at $50^{\circ} \mathrm{C}$ for $5 \mathrm{hr}$, and RNase-digested at $22^{\circ} \mathrm{C}$ for $90 \mathrm{~min}$. The sample was ethanol-precipitated in 2 equal aliquots, one set of which was prepared for electrophoresis on a $4 \%$ polyacrylamide, $7 \mathrm{~m}$ urea-denaturing gel, as described in Materials and Methods. The other set is shown in Figure 6. Asterisks, bands generated by the Brattleboro point deletion. $C$, control; $S, 6 \mathrm{~d}$ CISL; $x c$, xylene cyanol. Electrophoretic origin is not shown.

length AVP protected cRNA, and bands 5', the 151-nucleotide AVP cRNA protected by the OT region of high homology. The control levels for both AVP- and OT-protected cRNAs (Fig. 5, lane C) were increased in CISL-treated rats (lane S). An electrophoretic pattern similar to that seen in the RNase digestion time course for 90 min (Fig. 2) was observed for control and CISL-treated Brattleboro DI RNAs. Note both the appearance of bands 2 and 6 due to endonuclease cleavage at the deletion mismatch, and that DI rats contain significantly less AVPd mRNA compared to the levels of AVP mRNA in either LE or $\mathrm{HZ}$ rats. Levels of AVPd and OT mRNAs were increased following $6 \mathrm{~d}$ of CISL. The pattern resulting from protection with control $\mathrm{HZ}$ magnocellular RNA was similar to that observed in the LE. Following CISL, however, HZ mRNA from both the $\mathrm{PVN}$ and SON clearly began to contain a significant proportion of AVPd mRNA. Although difficult to see in Figure 5, with longer exposures, control hypothalamic HZ mRNA could be shown to contain barely detectable levels of AVPd mRNA in both the PVN and SON.
Figure 6 illustrates the pattern resulting from samples identical to those used in Figure 5, but electrophoresed on a nondenaturing polyacrylamide gel. The number of double-stranded protected bands was effectively reduced to 2 for all 3 species of rat. This method greatly simplified the quantitation of specific mRNAs, since losses due to single-strand endonuclease nicking were avoided. Although nondenaturing electrophoresis failed to differentiate between AVP and AVPd mRNAs, the decreased expression of AVPd mRNA in the DI rat relative to that of LE and $\mathrm{HZ}$ rats became more readily apparent. With much longer exposures, very faint bands, corresponding to low levels of double-stranded cleavage at the deletion site, could be detected; these generated bands 2 and 6, and, at the G:G mismatch within band $5^{\prime}$, generated bands 8 and 9 .

Protection of OT cRNA by the same set of magnocellular mRNAs gave very comparable results to those above. Figure 7 shows the full-length protected doublet of band $\mathrm{A}^{\prime}$ present in $\mathrm{LE}, \mathrm{HZ}$ and DI rats. Figure 7 clearly illustrates, as does Figure 6 , the increased expression of both AVP and OT mRNAs in 

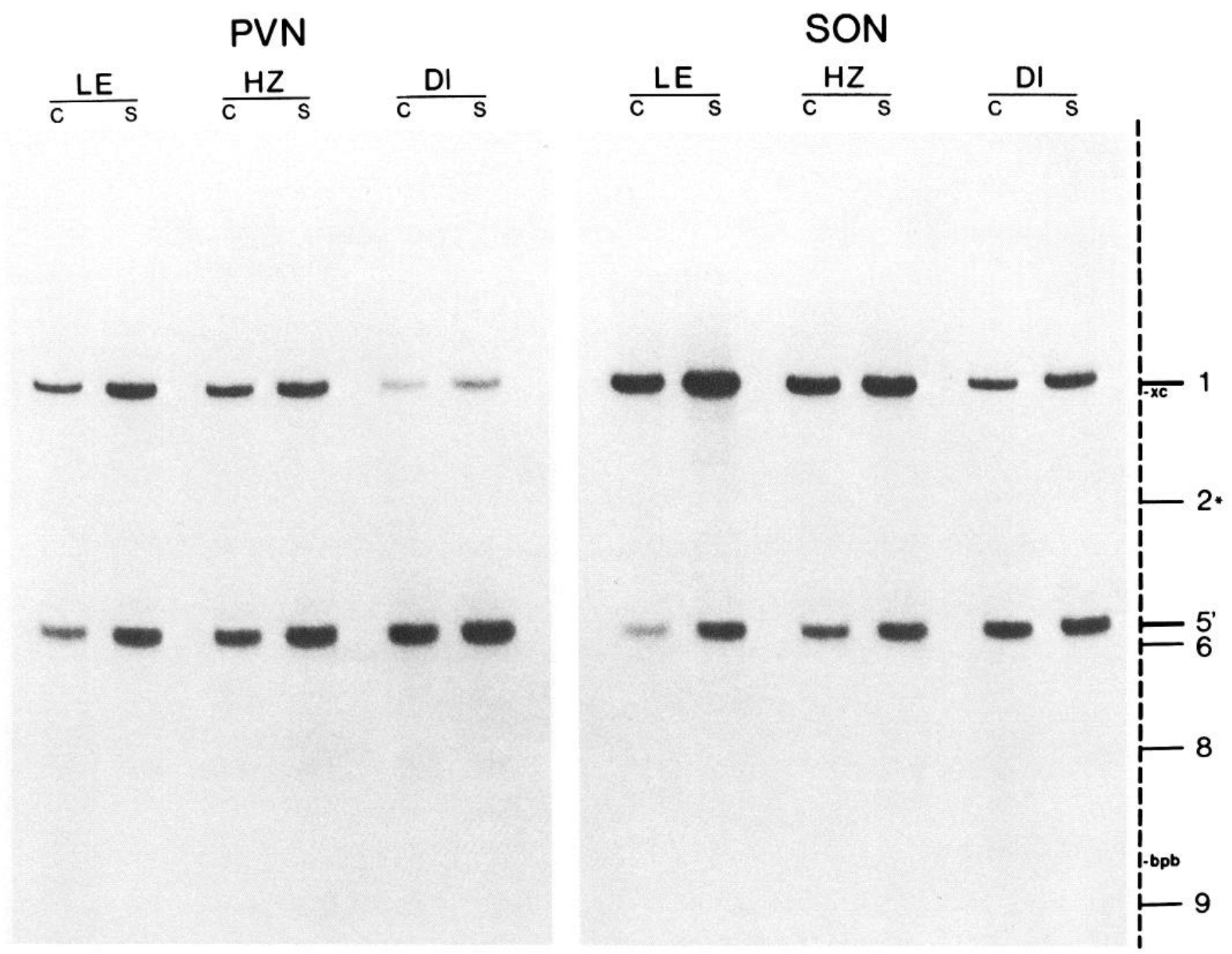

Figure 6. Nondenaturing gel electrophoresis of AVP cRNA fragments protected by control and CISL RNAs. A sample aliquot corresponding to that used in Figure 5 electrophoresed on a native $4 \%$ acrylamide gel. Asterisks, bands generated by the Brattleboro point deletion. $C$, control; $S$, 6 $\mathrm{d}$ CISL; $x c$, xylene cyanol; $b p b$, bromophenol blue. Electrophoretic origin is not shown.

each genotype following $6 \mathrm{~d}$ of CISL. The high levels of expression of OT mRNA in the control DI animal-levels more comparable to the salt-loaded values in LE and $\mathrm{HZ}$ rats-contrast greatly with the very low levels of AVPd mRNA. The highhomology region is poorly represented in band $\mathrm{C}$, since further cleavage at the C:C mismatch at position 242 occurred, generating bands $E^{\prime}$ and $\mathrm{G}^{\prime}$. Low levels of AVPd expression, RNase cleavage at the deletion site, and cuts at the $\mathrm{C}: \mathrm{C}$ mismatch make bands $C$ and $E^{\prime}$ almost undetectable in DI hypothalamic RNA. Bands $\mathrm{C}, \mathrm{D}$, and $\mathrm{E}^{\prime}$ were cleaved at either or both C:C and deletion mismatches to generate the overlapping bands $\mathrm{F}$ and $\mathrm{G}^{\prime}$, giving these bands the same levels of autoradiographic intensity found for $\mathrm{LE}$ and $\mathrm{HZ}$ rats.

The nondenaturing electrophoretic pattern observed for protected OT cRNA differed markedly from that seen with AVP cRNA (Fig. 8). Although the presence of AVPd mRNA remained masked, 4 discrete bands, rather than the expected 2 , were seen. Relative mobilities of the 2 faster-migrating bands identified them as bands $E^{\prime}$ and $G^{\prime}$, produced by double-stranded cleavage of the C:C mismatch.

Quantitation of OT and AVP allelic expression during CISL.
Figure 9 summarizes the expression of AVP/RNp I and OT/ RNp II mRNAs during CISL (Fig. 9, $A, B$, respectively). CISL could be shown to effectively and significantly increase cytoplasmic levels of AVP and/or AVPd, and of OT mRNAs in all 3 genotypes. The 34.4 and 83.6 amol AVPd mRNA detected in the PVN and SON nuclei, respectively, of the control DI rat were $45 \%$ of that detected in control $\mathrm{LE}$ and $\mathrm{HZ}$ nuclei. In the control HZ, $4.5 \pm 4.3 \mathrm{amol}$ of a total $86.1 \pm 5.3 \mathrm{amol}$, or $5.2 \%$, of PVN AVP mRNA was determined to be AVPd mRNA. In the SON, $13.8 \pm 9.2 \mathrm{amol}$ of a total $185.7 \pm 11.6 \mathrm{amol}$, or $7.4 \%$, was AVPd mRNA. With $6 \mathrm{~d}$ of CISL, these percentages changed to 18.1 and $21.7 \%$ AVPd mRNA in the PVN and SON, respectively. This represents an average 3.2-fold enrichment of AVPd mRNA using a paradigm in which the overall increase in AVP/AVPd mRNA was only $45-65 \%$.

The expression changes of OT mRNA in the CISL paradigm differed from those seen for AVP mRNA only in the DI rat. Levels of OT mRNA in control DI rat were not significantly different from the salt-loaded values observed in LE and HZ animals. All 3 groups realized increases in cytoplasmic OT mRNA levels of $50-60 \%$ following $6 \mathrm{~d}$ of CISL. 


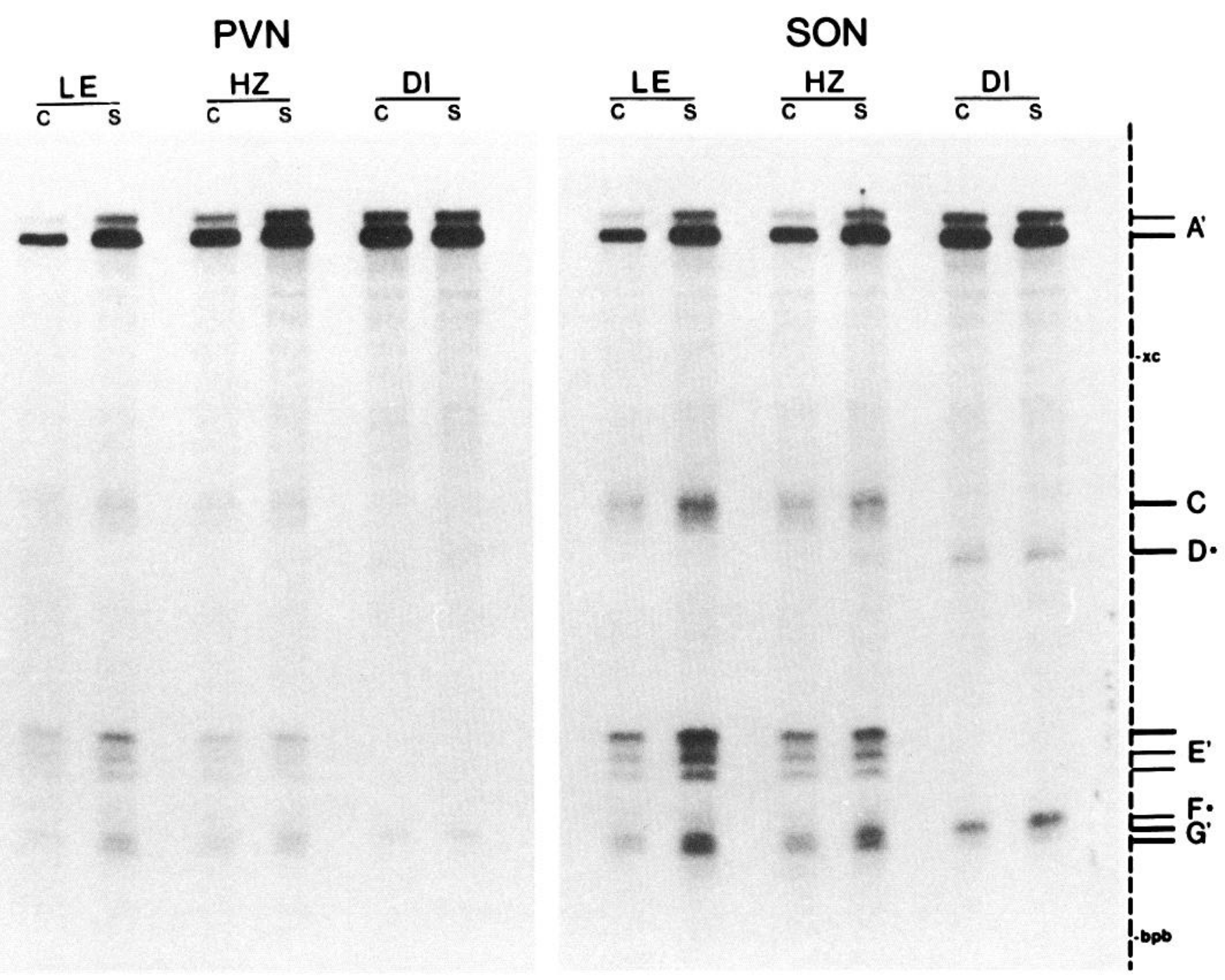

Figure 7. Denaturing gel electrophoresis of OT cRNA fragments protected by control and CISL RNAs. Total nucleic acids from individual magnocellular PVN and SON tissue punches were isolated, hybridized against $50.19 \mathrm{fmol}\left(1.63 \times 10^{6} \mathrm{dpm}\right)$ of OT cRNA, and processed as described in the legend to Figure 5. Asterisks, bands generated by the Brattleboro point deletion. $C$, control; $S, 6 \mathrm{~d}$ CISL; $x c$, xylene cyanol; $b p b$, bromophenol blue. Electrophoretic origin is not shown.

Molar ratios of AVP and OT mRNAs were 1.00:1.32 in the control PVN and 1.93:1.00 in the control SON for LE and HZ rats. Corresponding ratios of $1.00: 4.70$ and $1.00: 1.68$, respectively, were found in the control Brattleboro DI.

\section{Relative sensitivities of (mRNA:cRNA) mismatches}

The 2 orientations of nonhomologous mRNA:cRNA hybrids created in this study-OT mRNA:AVP cRNA and AVP mRNA: OT cRNA - provided an assortment of single, double and triple base-pair mismatches with varying degrees of RNase A and/or $T_{1}$ specificity and sensitivity. Table II begins to summarize the effectiveness of ribonuclease cleavage at each of 13 relevant sites with data derived from the RNase time course study (Fig. 2, Table I), and from the denaturing and nondenaturing gels of Figures 5-8.

Table IIA summarizes the effectiveness of cleavage at the Brattleboro point deletion. The guanine deletion at position 326 in the upper mRNA strand greatly destabilizes the nucleotide base pairs in positions $325-327$. RNase A will cleave at the $3^{\prime}$ side of single-stranded pyrimidines, as described in Materials and Methods. Additional RNase A cleavages at the position 327 cytosine, and an RNase $T_{1}$ cleavage at the $3^{\prime}$ side of guanine in position 325 were also possible. The former proved to be the more prevalent second cleavage. A second cut at the position 327 cytosine would excise the nonpaired cytosine 326 , effectively negating the destabilization induced by the Brattleboro mutation. This newly "repaired" match should be RNase-resistant. The poor efficiency of double-stranded cleavage at the deletion site $(5.88 \%$, Table II) suggests that this is indeed true.

Table IIB summarizes the observed cleavages at mismatches of OT mRNA:AVP cRNA hybrids. The locations of the 4 mismatches in Table IIB, labeled a-d, are schematically shown in Figure 3. The most interesting is mismatch a, a guanine purine : purine mismatch potentially recognized by RNase $T_{1}$. Calculated from the abundance of bands 7 and 8 , the cRNA strand site was cut with a frequency of $17.5 \%$ at $90 \mathrm{~min}$ of digestion. The G:G pairing differs from the deletion mismatch described above, and can be described as a semisymmetrical mismatch 


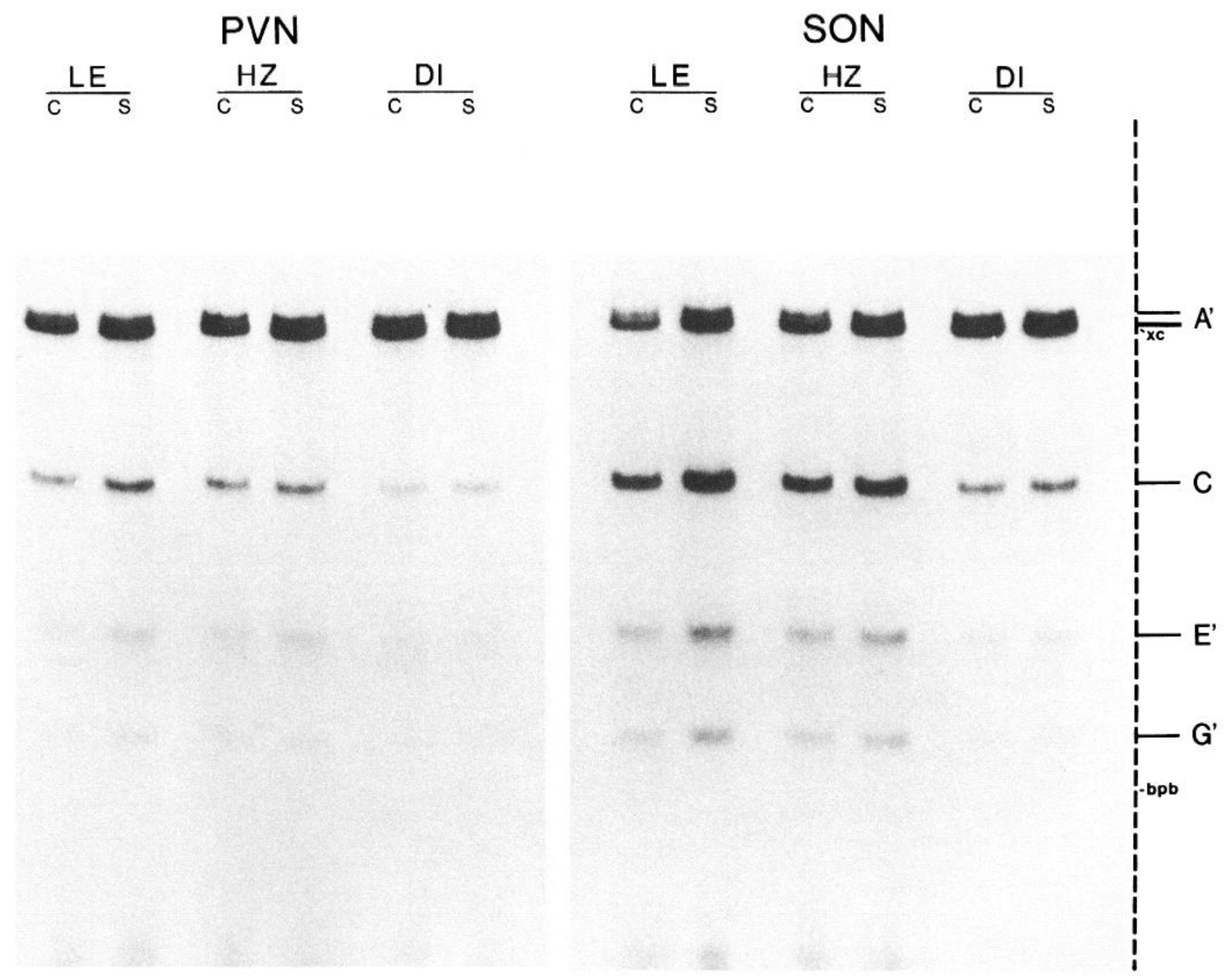

Figure 8. Nondenaturing gel electrophoresis of OT cRNA fragments protected by control and CISL RNAs. A sample aliquot corresponding to that used in Figure 7 electrophoresed on a native 4\% acrylamide gel. Asterisks, bands generated by the Brattleboro point deletion. $C$, control; $S$, 6 $\mathrm{d}$ CISL; $x c$, xylene cyanol; $b p b$, bromophenol blue. Electrophoretic origin is not shown.

(identical mismatched nucleotides with differing $3^{\prime}$ neighbors). A cleavage frequency of $17.5 \%$ at 2 independent strands would predict a double-stranded cleavage frequency of $3.1 \%$. A frequency of $7.36 \pm 0.42 \%$ was observed, possibly suggesting unequal efficiencies of cutting between the different neighboring nucleotides. Mismatch a contrasts nicely with mismatch i, found in AVP mRNA:OT cRNA hybrids (Table IIC). This cytosine pyrimidine: pyrimidine semisymmetrical RNase A-sensitive mismatch was cut with a single-stranded frequency of $72.6 \%$ at $90 \mathrm{~min}$. Double-stranded cleavage efficiency was determined to be $43.90 \pm 0.59 \%$, a value lower than the predicted $(72.6 \%)^{2}=$ $52.7 \%$. The large difference between the directly analogous mismatches, a and i, may reflect the different efficacies of RNases $A$ and $T_{1}$.

Cleavage at the double-mismatch $\mathrm{b}$ delineates the $5^{\prime}$ extent of band $5^{\prime}$. In almost all cases, double-mismatches were rapidly and efficiently cleaved (Myers et al., 1985a). As shown in Table II, b contains a double purine: pyrimidine mismatch, with one recognition site for RNase $A$ and none for $T_{1}$. Although not completely cut at $60 \mathrm{~min}$ of digestion, as shown in Figure 2 and Table I, the presence of a single, sharp band 5 ' in the nondenatur- ing gels of Figure 6 indicated that the cleavage was complete at $90 \mathrm{~min}$.

Table IIC illustrates a string of 3 individual, nonsymmetrical mismatches ( $\mathrm{f}-\mathrm{h})$ in AVP mRNA:OT cRNA, for which no evidence of RNase cleavage could be detected. The C:A mismatch of $f$ at position 169 contains a displaced adenosine in the cRNA strand that is not a cleavage site for either RNase $A$ or $T_{1}$. The $\mathrm{U}: G$ pyrimidine : purine mismatch of $\mathrm{h}$, although containing an RNase $T_{1}$ site at $G$, was not detectably cut at $90 \mathrm{~min}$. It has been shown previously that oligoriboguanylate forms a remarkably stable hybrid with oligodeoxyuridylate (Agarwal et al., 1981). Such a stable hybrid, if extending to RNA:RNA hybrids, would probably not provide an efficiently cleaved RNase $T_{1}$ site. The C: $U$ pyrimidine : pyrimidine mismatch of $g$ is not a stable mismatch, but it also is not detectably cleaved. It is not clear why this mismatch should be any more resistant than mismatch $i$, also a pyrimidine: pyrimidine pairing, but very efficiently cleaved. Although, pyrimidine: pyrimidine mismatches, because of their smaller pyrimidine ring structures, will not contribute to hydrogen-bonding stability in an existing duplex (Pauling and Corey, 1956), they would not significantly 

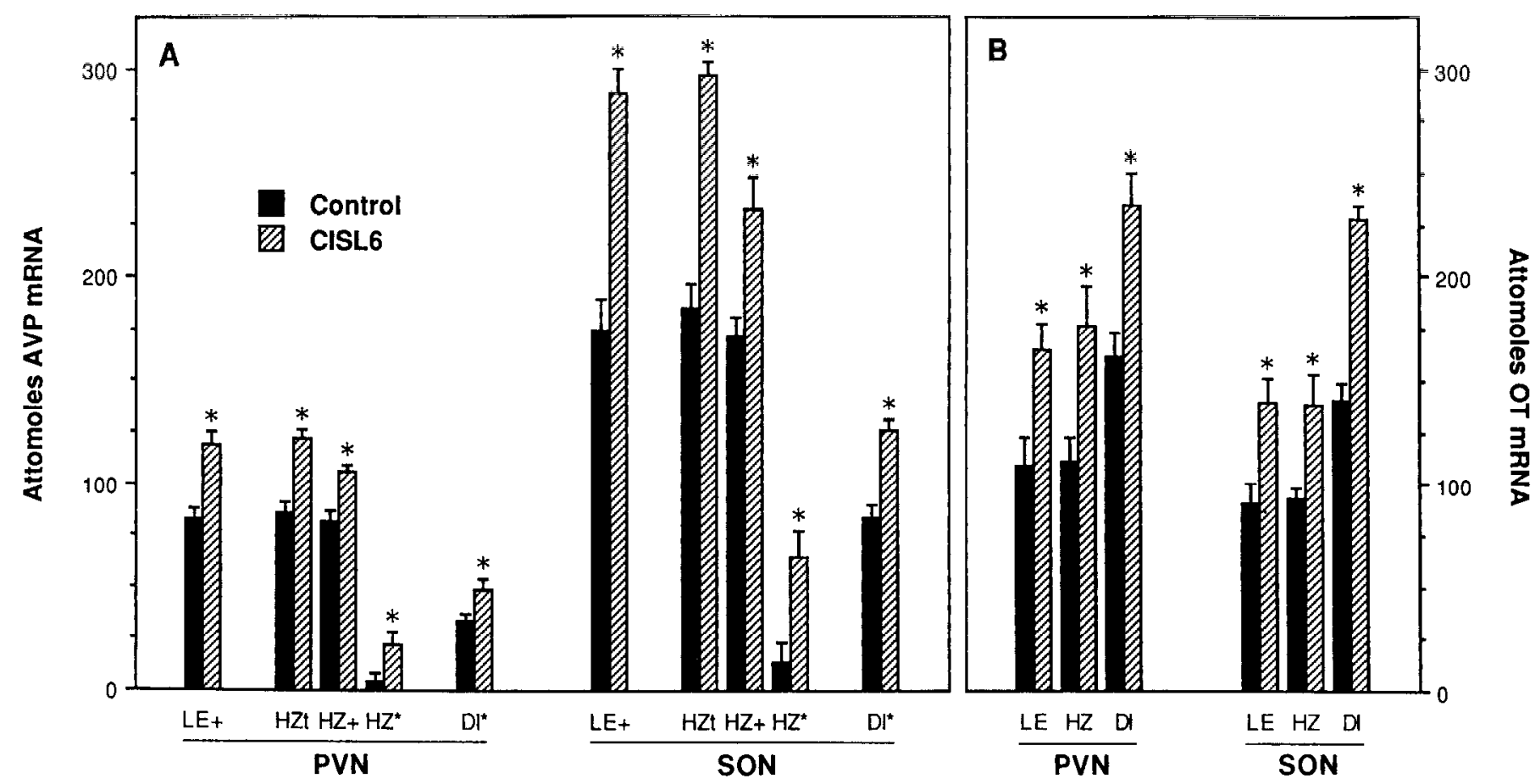

Figure 9. Summary of AVP and OT mRNA expression changes in response to $6 \mathrm{~d}$ of CISL. Absolute values for total AVP and OT quantitations were derived from nondenaturing gels only. The fraction of $\mathrm{HZ}$ normal AVP $(H Z+)$ versus $\mathrm{HZ}$ deletion-containing AVPd $\left(H Z^{*}\right) \mathrm{mRNA}$, comprising total HZ AVP mRNA $(H Z t)$ was determined by denaturing gel analysis. $L E+$, Long Evans AVP mRNA; the plus indicates that these AVP mRNAs were products from the same gene encoding $\mathrm{HZ}+$ in the HZ. Similarly, $D I^{*}$ indicates that these AVPd mRNA products were encoded by the same gene transcribing $\mathrm{HZ}^{*}$ in the HZ. $A$, Values are mean $\pm \mathrm{SEM}, n=6 . B$, Values are mean $\pm \mathrm{SEM}, n=4$.

destabilize it either. Perhaps the large differences in neighboring $\mathrm{G}: \mathrm{C}$ content $-50 \%$ for $\mathrm{i}, 100 \%$ for $\mathrm{g}$-contribute to the RNase sensitivities of these sites.

\section{Discussion}

Changes in the expression of magnocellular hypothalamic prohormone mRNAs during chronic intermittent salt-loading have previously been described and characterized in detail (Sherman et al., 1988). The adaptation of magnocellular neurosecretory neurons to prolonged periods of secretory activity involved a $3-4 \mathrm{~d}$ depletion of secretory peptides from posterior pituitary nerve terminals, with concomitant increases in cytoplasmic pools of secretory product mRNAs-an apparently concerted biosynthetic effort to maintain effective plasma hormone concentrations in the face of a chronically increased demand. The studies presented in this paper, however, explore a different aspect of neuronal adaptation to chronic secretory stimuli, describing the regulation of expression of a mutant-containing mRNA coding not only for an important physiological hormone, but as an integral component in the feedback regulation of the hypothalamo-neurohypophyseal system (HNS).

The identification and isolation of cDNA clones for SpragueDawley rat AVP and OT permitted the development of easier, more reproducible AVP mRNA quantitations than were reported in our earlier studies with oligonucleotides (Sherman et al., 1986a, b), and allowed the unambiguous quantitation of OT mRNA (Sherman et al., 1988). Sequencing of several identified cDNAs for both AVP and OT gave almost complete agreement with rat genomic sequences determined earlier by Ivell and Richter (1984). It was unclear whether these rat genomic sequences reported by Ivell and Richter (1984) represented Sprague-Dawley, LE, or some other rat strain, so the necessity of extending our cloning efforts to obtain LE rat cDNAs suitable for the RNase protection requirements of the present study was obviated by the complete agreement of our sequences with those of the Brattleboro rat AVP gene reported by Schmale and Richter (1984). The partial OT cRNA used in the present study avoided a single base sequence discrepancy (polymorphism?) detected in the $3^{\prime}$ untranslated region of the OT cDNA (Fig. 1, position 577).

The solution hybridization/RNase protection assay was used for the identification of Brattleboro deletion-containing AVP mRNA (AVPd) within a population of normal AVP mRNA. This assay, beyond its ability to detect single base mismatches and deletions, has proven to be simple, very sensitive, and generally applicable to RNA quantitation (Winter et al., 1985; Gibbs and Caskey, 1987). The ability to cxpress quantitative RNA values in molar units has greatly aided studies involving multiple mRNA species and comparisons between in vitro RNA quantitation and in situ hybridization experiments. For the purposes of this study, the combination of RNases $A$ and $T_{1}$ were required to facilitate the differentiation between 2 types of heterologous mRNA:cRNA hybrids - AVP:AVPd hybrids of normal versus Bratleboro mRNA and AVP:OT hybrids. cRNA cleavage at the deletion mismatch in AVP:AVPd hybrids proved to be relatively efficient ( $82.9 \%$; Table IIA), resulting in 2 easily detected bands (Figs. 2, 5). It is unclear why the effectiveness of single-stranded cRNA cleavage did not progress beyond $83 \%$. The $83 \%$-cleaved plateaus at 90 and 120 min suggested either a loss in enzymatic activity, the occurrence of nondeletion-containing AVP mRNA in the Brattleboro homozygote, or a subpopulation of "stable" deletion mismatches. Although no truly satisfactory explanation has been found, the latter possibility remains the most likely of the 3 , and has been postulated in 
Table II. RNase A/T 1 Sensitivity of AVP:AVPd and AVP:OT mRNA Mismatches.

\begin{tabular}{|c|c|c|c|c|c|c|c|c|}
\hline \multicolumn{4}{|c|}{ A. Brattleboro AVP mRNA:cRNA cleavages: } & \multicolumn{4}{|c|}{ single-stranded $\S$} & \multirow{2}{*}{$\begin{array}{c}\text { double stranded } ¥ \\
90 \mathrm{~min} \\
\end{array}$} \\
\hline Mismatch & Sequence & Position ${ }^{\circ}$ & RNase & $30 \mathrm{~min}$ & $60 \min$ & $90 \min y$ & $120 \mathrm{~min}$ & \\
\hline Brattleboro & $\mathrm{GC}^{\wedge} \mathrm{GA}$ & & & & & & & \\
\hline Deletion & ${ }^{\star} \mathrm{CG}_{1} \mathrm{C}_{1} \mathrm{CU}$ * & $\# 326$ & A & $58.1 \%$ & $71.9 \%$ & $82.9 \pm 4.1 \%$ & $83.6 \%$ & $5.88 \pm .52 \%$ \\
\hline \multicolumn{5}{|c|}{ B . OT mRNA:EcoRI-cut pGEM3-AVP 4c cRNA cleavages: } & \multicolumn{2}{|c|}{ single-stranded $\S$} & & double stranded $¥$ \\
\hline Mismatch & Sequence & Position 0 & RNase & $30 \mathrm{~min}$ & $60 \mathrm{~min}$ & $90 \min ¥$ & $120 \mathrm{~min}$ & $90 \mathrm{~min}$ \\
\hline \multirow[t]{2}{*}{ a } & $\mathrm{UC}^{\mathrm{G}} \mathrm{UG}$ & & & & & & & \\
\hline & ${ }^{\star} \mathrm{AG}_{\mathrm{G}} \mathrm{AC}{ }^{\star}$ & $\# 242$ & $\mathrm{~T}_{1}$ & $5.9 \%$ & $12.8 \%$ & $17.5 \pm 2.7 \%$ & $16.5 \%$ & $7.36 \pm .42 \%$ \\
\hline \multirow[t]{2}{*}{$\mathbf{b}$} & $\mathrm{C}^{\mathrm{CA}} \mathrm{CC}$ & & & & & & & \\
\hline & ${ }^{*} \mathrm{G}_{\mathrm{AC}} \mathrm{GG}$ * & \#340 & A & $46.1 \%$ & $71.3 \%$ & $98.8 \pm 1.8 \%$ & $99.3 \%$ & $100.0 \%$ \\
\hline \multirow[t]{2}{*}{ c } & $\mathrm{UG}_{\mathrm{AG}}^{\mathrm{U}}$ & & & & & & & \\
\hline & $\star A C_{G} U^{U} C^{\star}$ & $\# 358$ & $\mathrm{~T}_{1}$ & $\sqrt{ }$ & $\sqrt{ }$ & $\sqrt{ }$ & $\sqrt{ }$ & $?$ \\
\hline \multirow[t]{2}{*}{$\mathrm{d}$} & $\mathrm{C}^{\mathrm{CCG}} \mathrm{G}$ & & & & & & & \\
\hline & ${ }^{\star} \mathrm{G}_{\mathrm{C}, \mathrm{UA}} \mathrm{C}^{\star}$ & $\# 362$ & A & $78.0 \%$ & $92.3 \%$ & $100.0 \%$ & $100.0 \%$ & $?$ \\
\hline
\end{tabular}

C. AVP mRNA:HindIII-cut pSP65-OXY14c cRNA cleavages:

single-stranded $\S$

double stranded $¥$

\begin{tabular}{|c|c|c|c|c|c|c|c|c|}
\hline Mismatch & Sequence & Position 0 & RNase & $30 \mathrm{~min}$ & $60 \mathrm{~min}$ & $90 \min ¥$ & $120 \mathrm{~min}$ & $90 \mathrm{~min}$ \\
\hline \multirow[t]{2}{*}{$\mathbf{e}$} & $\mathrm{G}^{\mathrm{AC}} \mathrm{AG}_{\mathrm{AG}}$ & & & & & & & \\
\hline & ${ }^{\star} \mathrm{C}_{\mathrm{G}, \mathrm{U}}{ }^{\mathrm{UUC}}$ & $\# 160$ & $\mathrm{~A} / \mathrm{T}_{1}$ & $100.0 \%$ & n..d. & $100.0 \%$ & n.d. & $100.0 \%$ \\
\hline \multirow[t]{2}{*}{$\mathrm{f}$} & $\mathrm{CU}^{\mathrm{C}} \mathrm{CC}$ & & & & & & & \\
\hline & ${ }^{*} \mathrm{GA}_{\mathrm{A}} \mathrm{GG}$ * & \#169 & - & $0.0 \%$ & n.d. & $0.0 \%$ & n.d. & $0.0 \%$ \\
\hline $\mathrm{g}$ & $\begin{array}{c}{ }^{\mathrm{GG}} \mathrm{CC}_{\mathrm{U}}^{\mathrm{C} G \mathrm{CC}} \\
{ }^{*}\end{array}$ & $\# 178$ & A & $0.0 \%$ & n.d. & $0.0 \%$ & n.d. & $0.0 \%$ \\
\hline \multirow[t]{2}{*}{$\mathrm{h}$} & $\mathrm{CC}^{\mathrm{U}_{\mathrm{GG}}}$ & & & & & & & \\
\hline & ${ }^{\star} \mathrm{GG}_{\mathrm{G}} \mathrm{CC}{ }^{\star}$ & $\# 181$ & $\mathrm{~T}_{1}$ & $0.0 \%$ & n.d. & $0.0 \%$ & n.d. & $0.0 \%$ \\
\hline \multirow[t]{2}{*}{$\mathrm{i}$} & $\mathrm{UC}^{\mathrm{C}} \mathrm{UG}$ & & & & & & & \\
\hline & ${ }^{*} \mathrm{AG}_{\mathrm{C}} \mathrm{AC} *$ & $\# 242$ & $\mathbf{A}$ & $26.3 \%$ & n.d. & $72.6 \pm 0.9 \%$ & n.d. & $43.90 \pm .59 \%$ \\
\hline \multirow[t]{2}{*}{$\mathrm{i}$} & $\mathrm{C}^{\mathrm{UG}} \mathrm{CC}$ & & & & & & & \\
\hline & ${ }^{*} G_{G_{I}} G G *$ & $\# 340$ & $\mathrm{~A} / \mathrm{T}_{1}$ & $89.7 \%$ & n.d. & $100.0 \%$ & n.d. & $100.0 \%$ \\
\hline \multirow[t]{2}{*}{$\mathrm{k}$} & $\mathrm{UG}_{\mathrm{AG}}$ & & & & & & & \\
\hline & ${ }^{\star} \mathrm{AC}_{\mathrm{A}} \mathrm{UC}$ * & \#358 & - & $\sqrt{ }$ & n.d. & $\sqrt{ }$ & n.d. & $?$ \\
\hline \multirow[t]{2}{*}{1} & $\mathrm{C}^{\mathrm{GAU}} \mathrm{G}_{\mathrm{G}}$ & & & & & & & \\
\hline & ${ }^{*} G_{G_{1} G_{C} C}{ }^{\star}$ & $\# 362$ & $\mathrm{~A} / \mathrm{T}_{1}$ & $100.0 \%$ & n.d. & $?$ & n.d. & $?$ \\
\hline
\end{tabular}

$\wedge=\mathrm{G}$ deletion in Brattleboro $\quad \star=$ borders [32]P-labeled cRNA strand $\quad 0=$ refers to Fig. 1

? = not determinable; fragments generated by these cleavages are too small to be detected by this method

$V=$ in (B) this cleavage not distinguishable from site (d), or in (C) not a cleavage site by RNases $A$ or T1

n.d. = not determined $\quad ¥=$ Mean \pm S.E.M. $(n=12) \quad \S=$ ave. of two values except for $90 \mathrm{~min}$. 
other studies involving incomplete cleavage at known mismatches (Myèrs êt âl., 1985a: Wintér êt al., 1985). Another unresolved technical problem with the protection assay involves the reproducible generation of doublet and triplet protected bands where there should be only one. Results from our studies, and from others, suggest that extraneous bands form as the result of 2 different mechanisms: (1) nibbling back from one end at pyrimidine-rich RNase A-sensitive sites (Myers et al., 1985a), or (2) single-stranded endoribonuclease nicking at reproducible sites. The 2 mechanisms can be distinguished by the electrophoretic behavior of protected bands on denaturing versus nondenaturing gels. Bands $\mathrm{A}^{\prime}$ represent a clear example of doublets resulting from mechanism (1); the retention of this doublet on nondenaturing gels (compare Fig. 7 with Fig. 8) indicates the complete digestion of one end of the double-stranded duplex. Bands 5', 8', $E^{\prime}$, and $G^{\prime}$, on the other hand, represent examples of mechanism (2), because the doublet and triplet bands migrate as single, intact bands on nondenaturing gels. As with the singlestranded cleavage at the deletion mismatch, the integrity of the double-stranded hybrid was maintained. The possibility still exists that sequence heterogeneity between Sprague-Dawley cRNAs and Long Evans mRNAs may be the cause for these extraneous bands.

The RNase sensitivities of the many mismatches discussed in this paper are in general agreement with similar studies involving different mutations (Myers et al., 1985a; Winter et al., 1985; Gibbs and Caskey, 1987). The huge variability observed between these studies, however, indicates that more than merely knowledge of the specific mismatch is involved in the prediction of RNase sensitivity. Continued studies of this nature should allow a greater data set from which regions of consensus regarding varying RNase susceptibility can be deduced.

The detection of AVPd mRNA in the Brattleboro $\mathrm{HZ}$ indicates that both AVP alleles are transcribed. This is not surprising. Since the only known defect in the Brattleboro AVP gene is the single point deletion in the coding sequence (Schmale and Richter, 1984), and since AVPd mRNA is expressed in the DI, there is no a priori reason to assume a transcriptional difference. The low levels of AVPd RNA in the DI and the small fraction of AVPd RNA detected in the HZ indicate, however, that at least one component of mutant AVP allele gene expression is adversely affected by the point deletion. We showed earlier (Sherman et al., 1988, the previous paper), and again in the present study, that the osmotic regulation of AVPd RNA expression in DI rats remains similar to that in normal rats. The mutant allele of the $\mathrm{HZ}$ animal similarly retains its ability to osmoregulate, increasing its fractional content of total AVP/ AVPd mRNA from an average of 6.3 to $19.9 \%$ with $6 \mathrm{~d}$ of CISL. These results suggest that the regulatory control of transcriptional mechanisms for the expression of AVPd mRNA are also intact. The low levels of cytoplasmic AVPd mRNA, therefore, must result from posttranscriptional events. A proposed mechanism consistent with (1) the low relative cytoplasmic content of AVPd mRNA in the Brattleboro HZ and DI, (2) the retention of AVPd gene osmoregulation, and (3) the surprisingly large increase in AVPd fractional content with salt-loading in the Brattleboro $\mathrm{HZ}$ is a decrease in the effective half-life of AVPd mRNA brought on directly by its point deletion, or, more likely, as a consequence of its poor translatability. Although the fold increases of AVP and AVPd mRNAs in the HZ following saltloading were widely discrepant ( 1.5 versus 3.6 -fold, respective$1 y$ ), the molar increases in messenger RNA were quite compa- rable: 18.8 versus 15.5 in the PVN, and 60.7 versus 50.8 in the SON, respectively. The very small AVPd mRNA pool sizes of

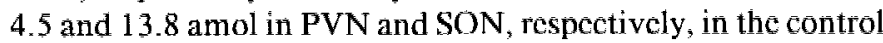
Brattleboro $\mathrm{HZ}$ would be altered to a much greater extent by this influx of newly transcribed RNA. Why, then, do control DI Brâttleboro ràts, wîth 2 mutant alleles for AVP, contain much more than twice the concentration of AVPd mRNA than do conontrol HZs (they contain nearly 7 times)? This apparent discrepancy can be resolved by an examination of neuropeptide mRNA content data and posterior pituitary neuropeptide content data for AVP, OT, CCK8, and peptides derived from prodynorphin (Sherman et al., 1988), which demonstrate that, biochemically, DI rats look and behave like chronically salt-loaded rats. Levels of AVPd mRNA in the DI rat were, in fact, approximately $130-160 \%$ higher, and, in the salt-loaded DI, greater than $200 \%$ higher, than the concentrations of AVPd mRNA detected in the salt-loadcd $\mathrm{HZ}$. These numbers suggest that the increased expression of AVP mRNA during chronic osmotic challenge also involves the transcription of both AVP alleles. The one functional AVP allele in the Brattleboro $\mathrm{HZ}$ does not fully compensate for the loss of its companion. This may account for the observed distinct phenotypic expression of the Brattleboro HZ (Valtin, 1982), and explains the semirecessive inheritance pattern of the AVPd gene.

The results obtained and the conclusions reached in this study, although relatively unique due to the regulatory relationships of the peptide hormones involved, are consistent in many respects with the few other examples of $\mathrm{HZ}$ expression in the literature. The coordinate expression of both alleles of a gene in a diploid somatic cell is the seldom discussed normal situation, since methods to distinguish between expressed alleles have only recently become available. Studies examining the dual expression of normal and mutant $\mathrm{c}-\mathrm{Ki}$-ras alleles in some human tumor cell lines, for example, demonstrate that the mutant allele can be expressed to a greater degree than the normal allele (Winter et al., 1985), an interesting apposing corollary to the results presented here. Results more similar to those in the Brattleboro rat were observed in the hypogonadic hpg mouse. A partial deletion of the gonadotropin-releasing hormone (GnRH) gene resulted in continued transcription, but low apparent expression, possibly owing to a shortened half-life of mutant GnRH mRNA (Mason et al., 1986). Studies comparable to those with Brattleboro $\mathrm{HZ}$ were not presented with $\mathrm{hpg} / \mathrm{H}$ $\mathrm{HZ}$, however. Both diabetes insipidus and hypogonadism are autosomal recessive mutations in which expression of the normal allele results in a near normal phenotype. The X-linked recessive mutations in the hypoxanthine phosphoribosyltransferase (HPRT) gene causing Lesch-Nyhan syndrom result in a far smaller frequency of $\mathrm{HZ}$. Studies in $\mathrm{HZ}$ females have not been reported, although, in affected males containing the one mutant allele, the expression of a wide variety of mutations was easily detected by RNase protection (Gibbs and Caskey, 1987). Many other studies not in brain, including the huge literature involving $\beta$-thalassemias, sickle-cell anemia, $\alpha_{1}$-antitrypsin deficiency, and familial hypercholesterolemia, all represent good examples of instances in which DI and/or HZ expression studies of mutant alleles have contributed important information on the regulatory processes of inheritable disease.

One final note regarding the data presented here: The molar quantitation of AVP and OT mRNAs, coupled with several past immunohistochemical analyses on the distribution and numbers of magnocellular neurons in the LE hypothalamus, permit 
estimates to be made of the average number of AVP or OT mRNA molecules existing within the average PVN or SON neuron. An excellent, detailed study on $\mathbf{I E}$ AVP and OT by Rhodes et al, (1981) estimates that the combined SON and retrochiasmatic SON contains $3236 \mathrm{AVP}$ and $1443 \mathrm{OT}$ cells, and that the combined PVN and anterior commissural nucleus (ACN) contains $991 \mathrm{AVP}$ and $1790 \mathrm{OT}$ cells. These are the approximate cell groups included in the punch dissections used in the present study. Cell number counts in the Brattleboro rat were similar. Estimates based on these numbers would predict an average of $30,000-35,000$ AVP or OT mRNA molecules/ peptide=specific neuron in the control LE rat. Although few such determininations have been made in neural tissue, estimates of 25,000-30,000 proopiomelanocortin (POMC) mRNAs/intermediate pituitary cell or anterior pituitary corticotroph cell compare favorably (James L. Roberts, personal communication).

\section{References}

Agarwal, D. L., J. Brunstedt, and B. E. Noyes (1981) A general method for detection and characterization of an mRNA using an oligonucleotide probe. J. Biol. Chem. 256: 1023-1028.

Chang, J. C., and Y. W. Kan (1982) A sensitive new prenatal test for sickle-cell anemia. N. Eng. J. Med. 307: 30-32.

Fischer, S. G., and L. S. Lerman (1983) DNA fragments differing by singlc basc-pair substitutions are separated in denaturing gradient gels: Correspondence with melting theory. Proc. Natl. Acad. Sci. USA 80: 1579-1583.

Gibbs, R. A., and C. T. Caskey (1987) Identification and localization of mutations at the Lesch-Nyhan locus by ribonuclease A cleavage. Science 236: 303-305.

Green, M. R., T. Maniatis, and D. A. Melton (1983) Human $\beta$-globin pre-mRNA synthesized in vitro is accurately spliced in Xenopus oocyte nuclei. Cell 32: 681-694.

Guldenaar, S. E. F., P. Nahke, and B. T. Pickering (1986) Immunocytochemical evidence for the presence of a mutant vasopressin precursor in the supraoptic nucleus of the homozygous Brattleboro rat. Cell Tissue Res. 244: 431-436.

Ivell, R., and D. Richter (1984) Structure and comparison of the oxytocin and vasopressin genes from rat. Proc. Natl. Acad. Sci. USA 81: 2002-2010.

Ivell, R., H. Schmale, B. Krisch, P. Nahke, and D. Richter (1986) Expression of a mutant vasopressin gene: Differential polyadenylation and read-through of the mRNA $3^{\prime}$ end in a frame-shift mutant. EMBO J. 5: $971-977$.

Kidd, V. J., R. B. Wallace, K. Itakura, and S. L. Woo (1983) $\alpha_{1}{ }^{-}$ Antitrypsin deficiency detected by direct analysis of the mutation in the gene. Nature 304: 230-234.

Krisch, B., P. Nahke, and D. Richter (1986) Immunocytochemical staining of supraoptic neurons from homozygous Brattleboro rats by use of antibodies against two domains of the mutated vasopressin precursor. Cell Tissue Res. 244: 351-358.

Lehrman, M. A., J. L. Goldstein, M. S. Brown, D. W. Russell, and W. J. Schneider (1985) Internalization-defective LDL receptors produced by genes with nonsense and frameshift mutations that truncate the cytoplasmic domain. Cell 4l: 735-743.

Majzoub, J. A., A. Pappey, R. Burg, and J. F. Habener (1984) Vasopressin gene is expressed at low levels in the hypothalamus of the Brattleboro rat. Proc. Natl. Acad. Sci. USA 81: 5296-5299.

Maniatis, T., E. F. Fritsch, and J. Sambrook (1982) Molecular Cloning, A Laboratory Manual, p. 451, Cold Spring Harbor Laboratory, New York.

Mason, A. J., J. S. Hayflick, R. T. Zoeller, W. S. Young III, H. S. Phillips, K. Nikolics, and P. H. Seeburg (1986) A deletion truncating the gonadotropin-releasing hormone gene is responsible for hypogonadism in the hpg mouse. Science 234: 1366-1371.
Melton, D. A., P. A. Kriegg, M. R. Rebağliati, T. Mañiatis, K. Zinn, and M. R. (Green (1984) Efficient in vitro synthesis of biologically active RNA and RNA hybridization probes from plasmids containing a bacteriophage SP6 promoter. Nücl. Acids Res. 12: 7035-7056.

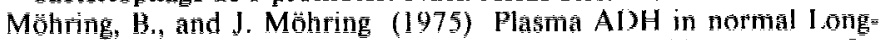
Evans rats and in Long-Fvane rats heterorygous and homozygous for hypothalamic diabetes insipidus Life Sci. $\overline{17}: 1307=1314$.

Myers, R. M., Z. Larin, and T. Maniatis (1985a) Detection of single base substitutions by ribonuclease cleavage at mismatches in RNA: DNA duplexes. Seience 230: 1242-1246.

Myers, R. M, L.S. Lerman, and T. Maniatis (1985b) A general method for saturation mutagenesis of doned DNA fragments. Science 229 : $242=247$.

$\bar{M}_{y e r s} \bar{R}, \bar{M}, \bar{N}$. Lumelsky, L. S. Lerman, and T. Maniatis (1985o) Detection of single base substitutions in total genomic DNA. Nature 313: $495-498$.

Orkin, S. H., P. F. R. Little, H. H. Kazazian, Jr., and C. D. Boehm (1982) Improved detection of the sickle mutation by DNA analysis. N. Eng. J. Med. 307: 32-36.

Pauling, L., and R. B. Corey (1956) Specific hydrogen-bond formation between pyrimidines and purines in deoxyribonucleic acids. Arch. Biochem. Biophys. 65: 164-181.

Rhodes, C. H., J. L. Morell, and D. W. Pfaff (1981) Immunohistochemical analysis of magnocellular elements in rat hypothalamus: Distribution and numbers of cells containing neurophysin, oxytocin, and vasopressin. J. Comp. Neurol. 198: 45-64.

Russell, J. T., M. J. Brownstein, and H. Gainer (1980) Biosynthesis of vasopressin, oxytocin, and neurophysins: Isolation and characterization of two common precursors (propressophysin and prooxyphysin). Endocrinology 6: 1880-1891.

Saul, G. B., II, E. B. Garrity, K. Benirschke, and H. Valtin (1968) Inherited hypothalamic diabetes insipidus in the Brattleboro strain of rats. J. Hered. 59: 113-117.

Schmale, H., and D. Richter (1984) Single base deletion in the vasopressin gene is the cause of diabetes insipidus in Brattleboro rats. Nature 308: 705-709.

Schmale, H., R. Ivell, M. Breindl, D. Darmer, and D. Richter (1984) The mutant vasopressin gene from diabetes insipidus (Brattleboro) rats is transcribed but the message is not efficiently translated. EMBO J. 3: 3289-3293

Sherman, T. G., and J. F. McKelvy (1982) Multiple forms of neurophysin precursor synthesized from Brattleboro rat hypothalamic RNA. Ann. NY Acad. Sci. 394: 82-95.

Sherman, T. G., O. Civelli, J. Douglass, E. Herbert, and S. J. Watson (1986a) Coordinate expression of hypothalamic pro-dynorphin and pro-vasopressin mRNAs with osmotic stimulation. Neuroendocrinology 44: 222-228.

Sherman, T. G., J. F. McKelvy, and S. J. Watson (1986b) Vasopressin mKNA regulation in individual hypothalamic nuclei: A Northern and in situ hybridization analysis. J. Neurosci. 6: 1685-1694.

Sherman, T. G., R. Day, O. Civelli, J. Douglass, E. Herbert, H. Akil, and S. J. Watson (1988) Regulation of hypothalamic magnocellular neuropeptides and their mRNAs in the Brattleboro rat: Coordinate responses to further osmotic challenge. J. Neurosci. 8: 3785-3796.

Valtin, H. (1982) The discovery of the Brattleboro rat, recommended nomenclature, and the question of proper controls. Ann. NY Acad. Sci. 394: 1-9.

Valtin, H., H. A. Schroeder, K. Benirschke, and H. W. Sokol (1962) Familial hypothalamic diabetes insipidus in rats. Nature 196: 11091110 .

Winter, E., F. Yamamoto, C. Almoguera, and M. Perucho (1985) A method to detect and characterize point mutations in transcribed genes: Amplification and overexpression of the mutant c-Ki-ras allele in human tumor cells. Proc. Natl. Acad. Sci. USA 82: 7575-7579.

Zinn, K., D. DiMaio, and T. Maniatis (1983) Identification of two distinct regulatory regions adjacent to the human $\beta$-interferon gene. Cell 34: 865-879. 